\title{
Anogenital distance as a toxicological or clinical marker for fetal androgen action and risk for reproductive disorders
}

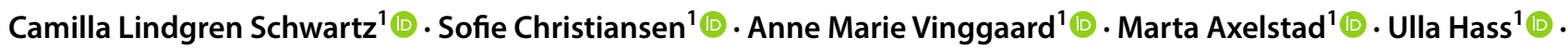 \\ Terje Svingen ${ }^{1}$ (1)
}

Received: 5 September 2018 / Accepted: 8 November 2018 / Published online: 14 November 2018

(c) The Author(s) 2018

\begin{abstract}
Male reproductive development is intricately dependent on fetal androgen action. Consequently, disrupted androgen action during fetal life can interfere with the development of the reproductive system resulting in adverse effects on reproductive function later in life. One biomarker used to evaluate fetal androgen action is the anogenital distance (AGD), the distance between the anus and the external genitalia. A short male AGD is strongly associated with genital malformations at birth and reproductive disorders in adulthood. AGD is therefore used as an effect readout in rodent toxicity studies aimed at testing compounds for endocrine activity and anti-androgenic properties, and in human epidemiological studies to correlate fetal exposure to endocrine disrupting chemicals to feminization of new-born boys. In this review, we have synthesized current data related to intrauterine exposure to xenobiotics and AGD measurements. We discuss the utility of AGD as a retrospective marker of in utero anti-androgenicity and as a predictive marker for male reproductive disorders, both with respect to human health and rodent toxicity studies. Finally, we highlight four areas that need addressing to fully evaluate AGD as a biomarker in both a regulatory and clinical setting.
\end{abstract}

Keywords Anogenital distance $\cdot$ Reproduction $\cdot$ Endocrine disruptors $\cdot$ Toxicology $\cdot$ Risks assessment

\section{Introduction}

Few things permeate our lives more than our sex and reproductive capacity, influencing not only our physical characteristics, but also behaviour and social perception. Ensuring proper reproductive development and life-long health therefore seems obvious, yet modern living is increasingly putting pressure on the processes of sexual differentiation and reproductive function. Exposure to endocrine disrupting chemicals (EDCs) during fetal life in both males and females

Camilla Lindgren Schwartz and Sofie Christiansen contributed equally to this work.

Electronic supplementary material The online version of this article (https://doi.org/10.1007/s00204-018-2350-5) contains supplementary material, which is available to authorized users.

Terje Svingen

tesv@food.dtu.dk

1 Division of Diet, Disease Prevention and Toxicology, National Food Institute, Technical University of Denmark, 2800 Kongens Lyngby, Denmark has been raised as particularly disconcerting, since this is the period when the sexual organs form and, in many respects, lay the foundation for adult reproductive health (Johansson et al. 2017; Skakkebaek et al. 2016). Much effort has thus been invested in understanding the relationships between fetal exposure to xenobiotics and reproductive disorders, as well as to devise testing strategies to screen chemicals for potential endocrine disrupting effects.

In males, reproductive disorders associated with impaired fetal testis development or function vary in both phenotype and time of manifestation. Often described by the 'testicular dysgenesis syndrome' hypothesis (Skakkebaek et al. 2016), these male disorders range from hypospadias and cryptorchidism in infants (Hsieh et al. 2008, 2012; Jain and Singal 2013; Thankamony et al. 2014), to low testosterone levels, impaired semen quality and fertility issues in adult men (Eisenberg et al. 2011, 2012; Mendiola et al. 2011). Because of this complexity, it is difficult to adopt a single biomarker to use in animal toxicity studies aimed at testing chemicals for potential adverse effects on male reproductive health. The anogenital distance (AGD), however, is considered a broad biomarker capable of both retrospectively determine 
early-life androgen disruption and predict late-life reproductive disorders in male offspring (Dean and Sharpe 2013; Thankamony et al. 2016).

The AGD refers to the distance between the anus and the external genitalia, and is approximately twice the length in male compared to female new-borns. This sexual dimorphism is apparent in rodents as well as humans (SalazarMartinez et al. 2004; Thankamony et al. 2009) and is a consequence of the androgen-driven dimorphic differentiation of the two sexes (Fig. 1). This sexual bifurcation extends to the perineum, where a muscular complex develops in males, but not in females. A short male AGD is, therefore, considered a marker of disrupted androgen action. In rodents, a short male AGD largely predicts the same adverse effect outcomes as in humans. In fact, the idea of investigating AGD in human epidemiological studies came from rodent developmental and reproductive toxicity studies, where AGD had been used for decades as a marker of impaired fetal androgen action and regarded as a an adverse outcome (Tables 1,2).

In this review, we discuss current knowledge concerning AGD measurements, both as a clinical marker in humans and as a morphometric measure of fetal androgen disturbance in rodent toxicity studies. We have collated a growing body of toxicological studies that have reported on AGD measurements to gain a better overview of what evidence support the exclusive androgen-driven masculinization thesis, or to tease out other potential mechanisms that may lead to similar effects on AGD. However, first, to better appreciate why the AGD is a useful marker to assess early-life androgen disruption, we need to broadly outline how the two sexes develop.

\section{Sexual differentiation and the importance of early androgen signaling}

\section{From gonadal sex determination to testosterone synthesis}

At first, the male and female embryos are morphologically indistinguishable and only differentiate down two distinct trajectories after the appearance of either testes or ovaries. The specification of reproductive sex, or gonadal sex determination, is genetically controlled by the Y-linked sex determining gene Sry that is expressed in XY, but not in $\mathrm{XX}$ gonads, triggering testis differentiation in male fetuses (Koopman et al. 1991; Svingen and Koopman 2013). Subsequently, the testes differentiate into compartmentalized organs comprising testis cords and an interstitial space. Fetal Leydig cells differentiate within the interstitium and become the main site of androgen synthesis necessary for development of accessory male sex organs and general masculinization of the body (Svingen and Koopman 2013). The testes also produce the peptide hormone Insulin-like factor 3 (INSL3) that is required for transabdominal testicular descent (Nef and Parada 1999), and anti-Müllerian hormone (AMH) which ensures regression of the Müllerian ducts; a paired structure that otherwise would develop into the female reproductive tract (Behringer 1994; Josso et al. 1993). In simple terms, the absence of these 'male-centric' factors allows for the female reproductive system to develop.

\section{Testosterone drives masculinization}

Simply put, testosterone regulates secondary sex differentiation. If testosterone is present, the body will develop male traits; if not present, the body will develop female traits (Fig. 1). However, the full picture is much more complex. First, many factors other than testosterone are involved, including AMH and INSL3 as mentioned above, but also others such as Hedgehog (Hh), Wingless-like (Wnt) and various growth factors. Second, androgen-dependent masculinization processes are likely influenced by actual hormone levels in target tissues, meaning that masculinization cannot be viewed as a simple 'on-off' switch, but rather a scenario, where more or less androgens can, to some degree, result in more or less masculine traits. From this viewpoint, it is more difficult to define when a morphometric change can be regarded as adverse or not. Nevertheless, as shown by Alfred Jost more than half a century ago (Jost 1947, 1953), androgens are the main drivers of male sex differentiation and are essential during a critical time window of development (MacLeod et al. 2010).

The fetal masculinization process involves numerous tissues and organs, including development of external genitalia and sex-specific differentiation of the perineum: the region between anus and genitalia (Fig. 1). In these tissues, the process seems largely governed by dihydro-testosterone (DHT) which is locally converted from testosterone by the enzyme $5 \alpha$-reductase. DHT acts by binding to and activating the Androgen receptor (AR), a nuclear hormone receptor responsible for regulating transcription of target genes (Fig. 2).

It has been suggested that the AGD is masculinized during development when AR activation stimulates the growth of the perineal muscles levator ani and bulbocavernosus (LABC) complex. In males, AR is expressed in non-myocytic cells of the LABC (Ipulan et al. 2014). Activation of $\mathrm{AR}$ in these cells prompts the growth of the LABC complex and the resulting size is thought to directly affect the AGD. Indeed, ablation of AR in rodents impairs development of the LABC complex and results in feminized male AGD (Ipulan et al. 2014; MacLean et al. 2008; Notini et al. 2005).

It is likely that more subtle changes in androgen levels, as for instance seen with fetal exposure to anti-androgenic compounds, can affect AGD by the same mechanism. This is supported by rodent toxicity studies, where a short AGD is 


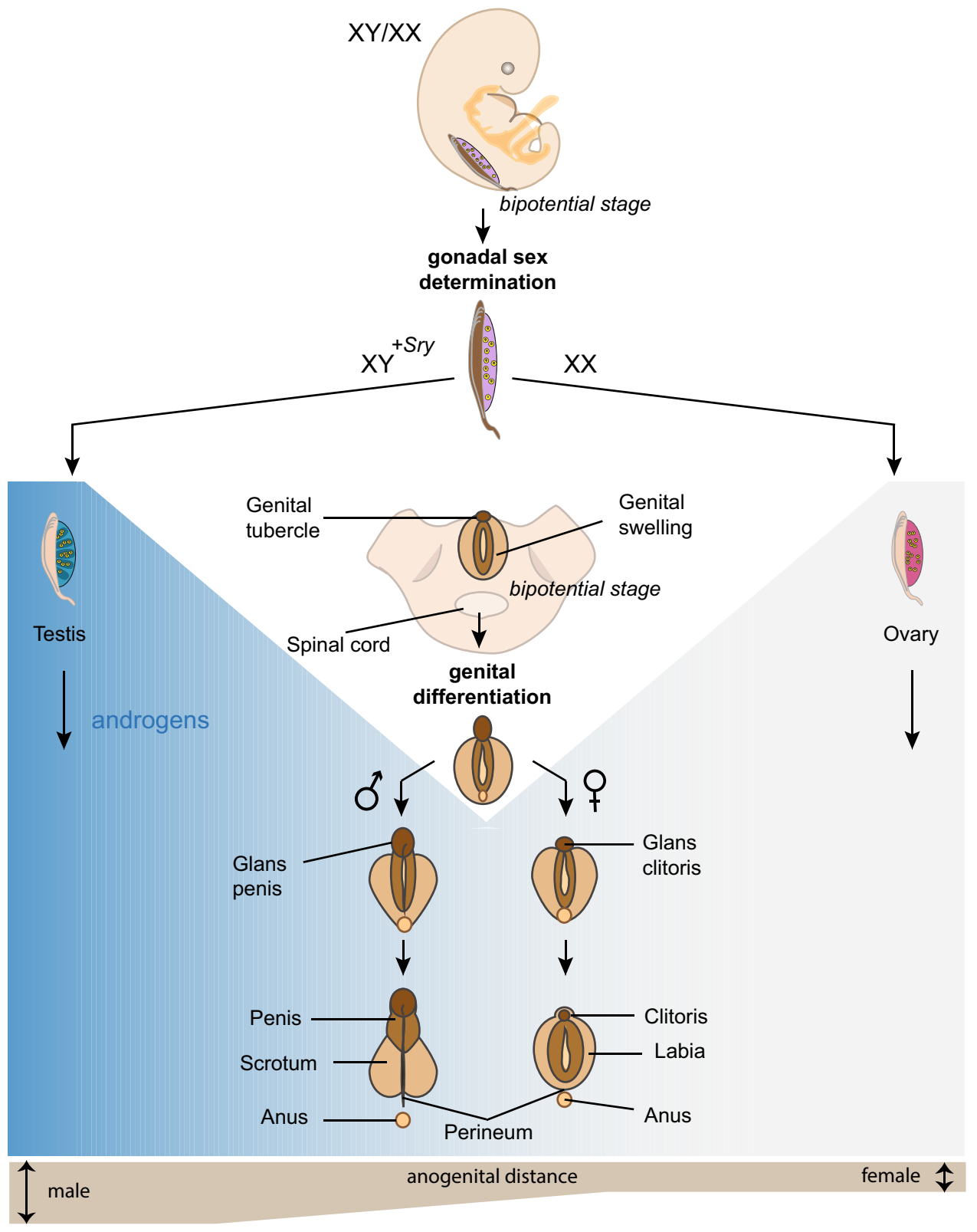

Fig. 1 Development of mammalian external genitalia. Initially, male (XY) and female (XX) fetuses are morphologically indistinguishable. During organogenesis, the bipotential gonadal ridges-located as paired structures running parallel on either side of the body midline-are instructed to differentiate into either testes or ovaries depending on the expression or not of the Y-chromosomal gene Sry in males and females, respectively. This takes place around gestational day 12 in rats and during gestational week 6 in humans. Following gonadal sex determination, the testes will quickly differentiate into compartmentalized structures comprising testis cords and an interstitial space. Steroidogenic Leydig cells appear in the interstitium and start synthesizing androgens-primarily testosterone-that are

often associated with a reduced LABC weight (Christiansen et al. 2008). There are, however, indications that effects on AGD are more complicated than just androgens stimulating muscle growth and anti-androgens that depress this. First, secreted into the circulation, where they will prompt androgen-sensitive tissue to masculinize. The absence of Leydig cells and androgens in ovaries allows for female differentiation to occur. Locally, in the perineum, testosterone is converted to DHT, which in turn can activate the Androgen receptor and initiate a regulatory cascade that instructs the tissue to develop into male external genitalia, including differentiation of the LABC muscular complex, fusion of the genital swellings to form the scrotum, and growth of the genital tubercle into a penis. From this follows an elongation of the distance between genitalia and anus, referred to as the anogenital distance (AGD). On average, the male AGD is approximately twice that of female and it is a morphometric readout of fetal androgen exposure or activity

while AGD is thought to be relatively stable throughout life, the perineum is in fact responsive to postnatal changes in androgen levels (Kita et al. 2016; Mitchell et al. 2015). Second, certain EDCs have been found to induce both shorter 


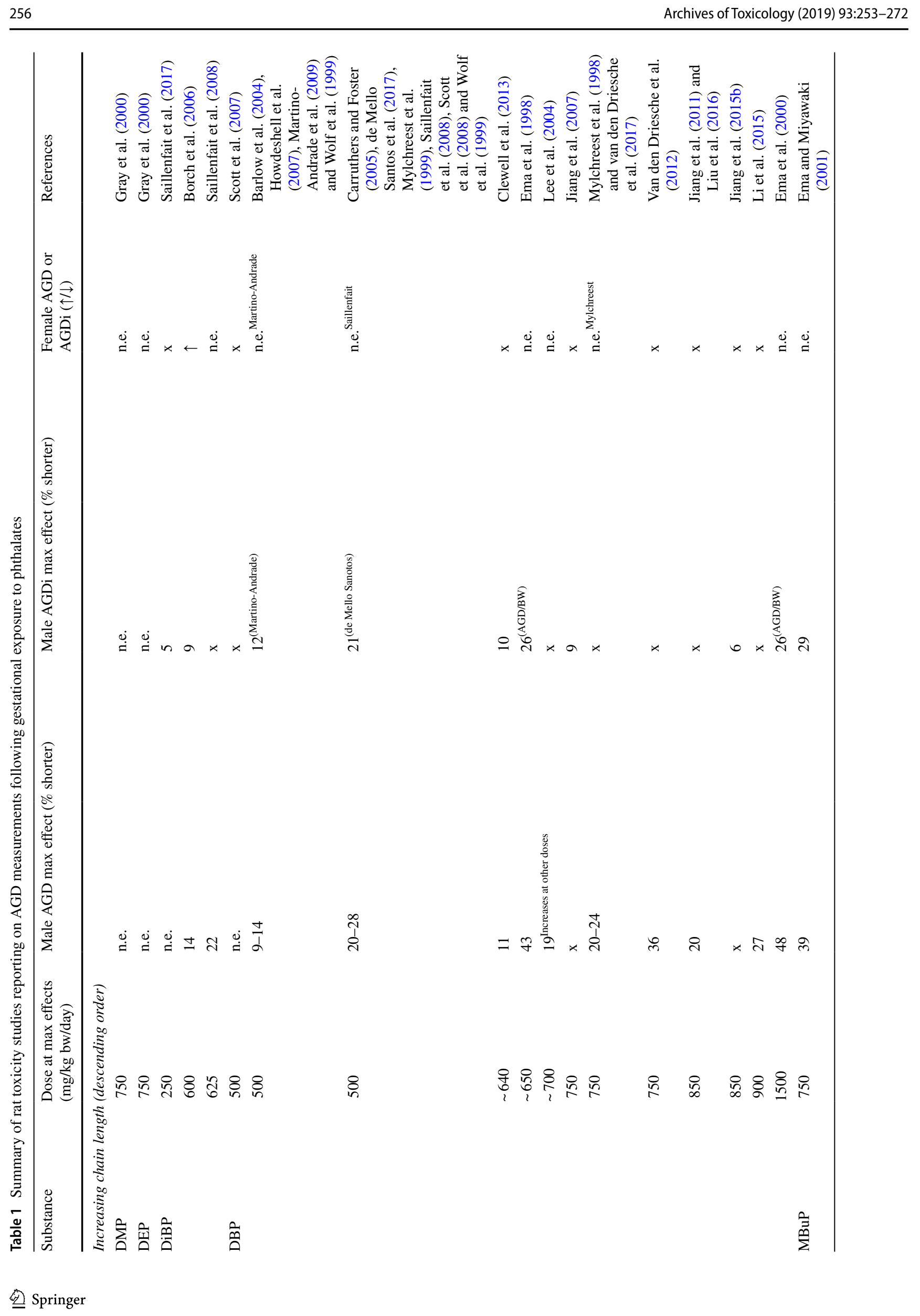




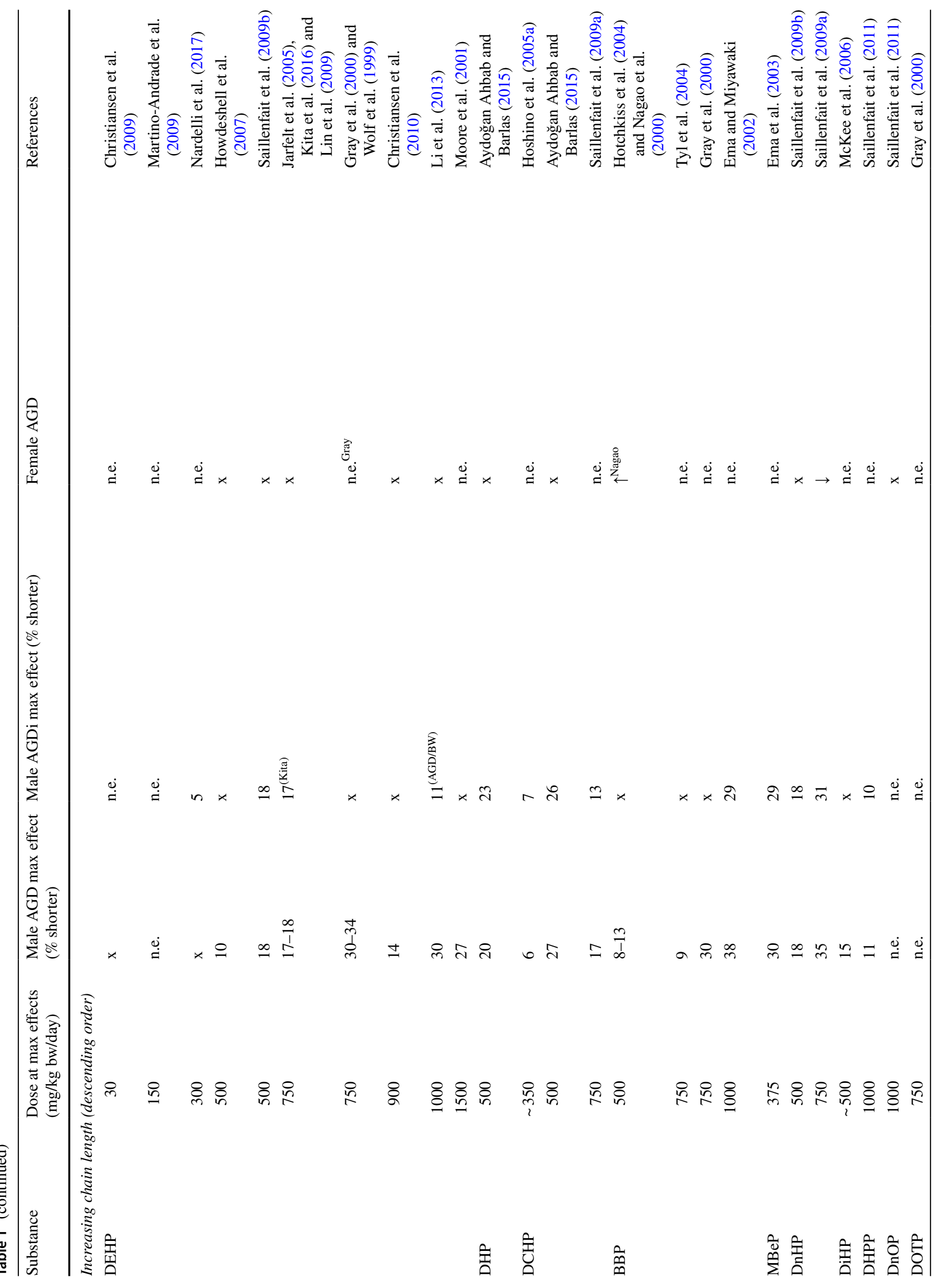




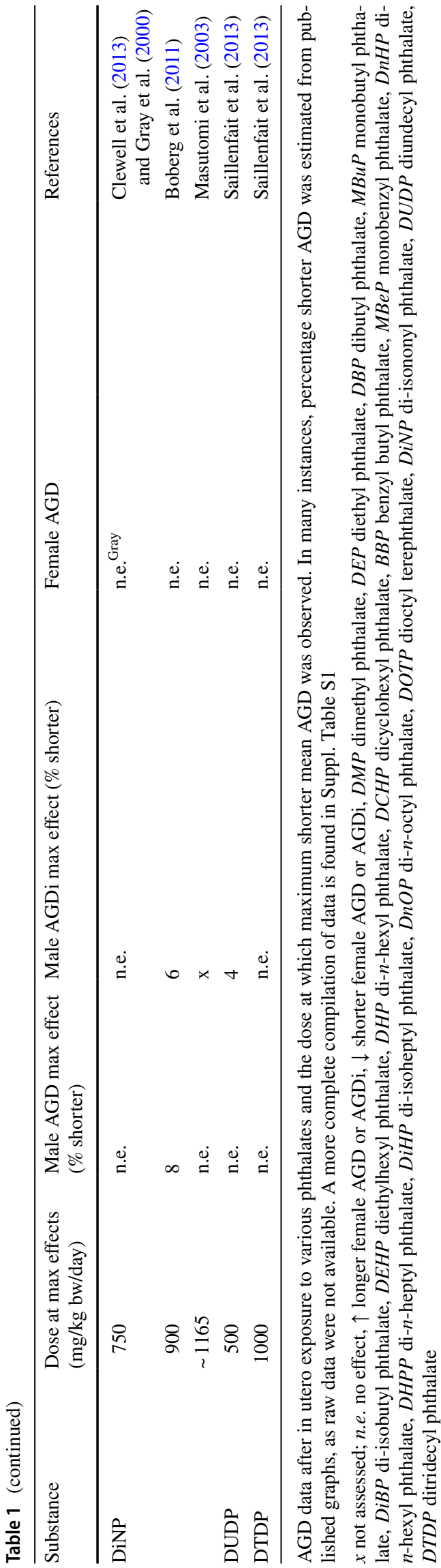

and longer female AGD or have multiple modes of action, as will be discussed later. Thus, more research is needed to fully understand how AGD is affected by fetal endocrine disruption.

\section{Anogenital distance: a biomarker for fetal hormone action and late-life reproductive health}

A large number of studies now support various aspects of the 'testicular dysgenesis syndrome' (TDS) hypothesis. However, it has also become increasingly clear that the relationship between hormone disruption and disease outcome is not always obvious. A simple reason for this is that male reproductive disorders can arise from various causes, not least genetic mutations or even genotypic predispositions. This can, in some instances, make it difficult to prove direct cause-effect relationships between chemical exposure and disease state in humans, especially if contributing genetics is present but not characterized. Another major complication is the considerable latency between exposure and disease manifestation, for instance, with regard to reduced sperm quality; a medical condition that can also be influenced by many other factors in the years between fetal life, birth, and adulthood. Hence, a single common biomarker that can predict a number of male reproductive disorders could prove valuable, both from a scientific and clinical point of view.

\section{AGD measurements in human epidemiology and medicine}

Fetal exposure to EDCs has been associated with a short AGD in new-born boys. Phthalates are the most frequently reported chemicals associated with a short AGD (Adibi et al. 2015; Bornehag et al. 2015; Bustamante-Montes et al. 2013; Marsee et al. 2006; Suzuki et al. 2012; Swan et al. 2005), but also other compounds including dioxins (Vafeiadi et al. 2013), bisphenol A (Mammadov et al. 2018; Miao et al. 2011) and mild analgesics (Fisher et al. 2016; Lind et al. 2017). Notably, several studies have not found significant correlations between exposure levels and short AGD in boys, including some phthalates (Jensen et al. 2016), dichlorodiphenyl-trichloroethane (DDT) (Bornman et al. 2016), triclosan (Lassen et al. 2016), and various pesticides (Dalsager et al. 2018). These discrepancies do not necessarily diminish the cause for concern, but rather highlight the challenges of obtaining evidence for causal relationships from human epidemiological studies.

With regard to reproductive disorders, many studies have reported significant correlations between short AGD in boys and for instance hypospadias (Cox et al. 2017; Gilboa et al. 2017; Hsieh et al. 2012; Singal et al. 2016), 
Table 2 Summary of rat toxicity studies reporting on AGD measurements following gestational exposure to compounds other than phthalates

\begin{tabular}{|c|c|c|c|c|c|}
\hline Substance & $\begin{array}{l}\text { Dose at max } \\
\text { effects }(\mathrm{mg} / \mathrm{kg} \text { bw/ } \\
\text { day) }\end{array}$ & Male AGD max effect ( $\%$ shorter) & $\begin{array}{l}\text { Male AGDi max } \\
\text { effect ( } \% \text { shorter) }\end{array}$ & $\begin{array}{l}\text { Female AGD } \\
\text { or AGDi }(\uparrow / \downarrow)\end{array}$ & References \\
\hline \multicolumn{6}{|l|}{ Drugs } \\
\hline Acetylsalicylic acid & 400 & 38 & $\mathrm{x}$ & n.e. & Gupta and Goldman (1986) \\
\hline Aniline & 93 & $\mathrm{x}$ & 20 & $\mathrm{x}$ & $\begin{array}{l}\text { Holm et al. (2015) (mouse } \\
\text { study) }\end{array}$ \\
\hline \multirow[t]{4}{*}{ Paracetamol } & 150 & $9^{a}$ & $10.5^{\mathrm{a}}$ & $\mathrm{x}$ & Kristensen et al. (2011) \\
\hline & 150 & $\mathrm{x}$ & 15 & $\mathrm{x}$ & $\begin{array}{l}\text { Holm et al. (2015) (mouse } \\
\text { study) }\end{array}$ \\
\hline & 350 & 8 & 9 & $\mathrm{x}$ & van den Driesche et al. (2015) \\
\hline & 360 & $\mathrm{x}$ & n.e. & n.e. & Axelstad et al. (2014) \\
\hline Dexamethasone & 0.1 & 10 & $\mathrm{x}$ & $\mathrm{x}$ & Van den Driesche et al. (2012) \\
\hline \multirow[t]{2}{*}{ Finasteride } & 0.1 & $\mathrm{x}$ & 9 & $\mathrm{x}$ & Christiansen et al. (2009) \\
\hline & 100 & 33 & $\mathrm{x}$ & $\mathrm{x}$ & Bowman et al. (2003) \\
\hline \multirow[t]{3}{*}{ Flutamide } & $16-20$ & $44^{\text {Kita }}$ & $41-42$ & $\mathrm{x}$ & $\begin{array}{l}\text { Hass et al. (2007); Kita et al. } \\
\quad(2016)\end{array}$ \\
\hline & 50 & $16-53$ & $\mathrm{x}$ & $\mathrm{x}$ & $\begin{array}{l}\text { Foster and Harris (2005) and } \\
\text { McIntyre et al. (2001) }\end{array}$ \\
\hline & 100 & $33-55$ & $\mathrm{x}$ & $\mathrm{x}$ & $\begin{array}{l}\text { Mylchreest et al. (1999), Scott } \\
\text { et al. (2007) and Welsh et al. } \\
\text { 2007) }\end{array}$ \\
\hline Ethinyl estradiol & $(0.00-0.05)$ & n.e. & n.e. & $(\uparrow)^{\text {Mandrup }}$ & $\begin{array}{l}\text { Ferguson et al. (2011), } \\
\text { Howdeshell et al. (2008) and } \\
\text { Mandrup et al. (2013) }\end{array}$ \\
\hline \multirow[t]{2}{*}{ Ketoconazole } & $(50)$ & n.e. & $\mathrm{x}$ & $\mathrm{x}$ & Wolf et al. (1999) \\
\hline & 50 & 8 & 11 & $\downarrow$ & Taxvig et al. (2008) \\
\hline \multicolumn{6}{|l|}{ Pesticides } \\
\hline \multirow[t]{3}{*}{ Epoxiconazole } & 3.75 & $5^{\mathrm{a}}$ & $5^{\mathrm{a}}$ & $\uparrow$ & Hass et al. (2012) \\
\hline & 15 & $7^{(\mathrm{PND} 0) \mathrm{a}}$ & $10^{(\mathrm{GD} 21) \mathrm{a}}$ & $\uparrow$ & Taxvig et al. (2007) \\
\hline & 50 & n.e. & n.e. & n.e. & Taxvig et al. (2008) \\
\hline Myclobutanil & 145 & $12^{\text {Increased }}$ & $\mathrm{x}$ & $\mathrm{x}$ & Goetz et al. (2007) \\
\hline \multirow[t]{3}{*}{ Prochloraz } & $(0.01-35)$ & n.e. & $\mathrm{x}$ & $(\uparrow)^{\text {Melching, Hass }}$ & $\begin{array}{l}\text { Christiansen et al. (2009), } \\
\text { Hass et al. (2012), Melching- } \\
\text { Kollmuss et al. (2017) and } \\
\text { Vinggaard et al. (2005) }\end{array}$ \\
\hline & 150 & $\mathrm{x}$ & 12 & $\uparrow$ & Laier et al. (2006) \\
\hline & 250 & 6 & $\mathrm{x}$ & $\uparrow$ & Noriega et al. (2005) \\
\hline \multirow[t]{2}{*}{ Propiconazole } & 50 & n.e. & n.e. & n.e. & Taxvig et al. (2008) \\
\hline & $\sim 158$ & $7^{\text {Increased }}$ & $\mathrm{x}$ & $\mathrm{x}$ & Goetz et al. (2007) \\
\hline \multirow[t]{2}{*}{ Tebuconazole } & $12.5-50$ & n.e. & n.e. & $(\uparrow)^{\text {Hass }}$ & $\begin{array}{l}\text { Hass et al. (2012) and Taxvig } \\
\text { et al. (2008) }\end{array}$ \\
\hline & 100 & n.e. & $10^{\text {Increased (only at GD21) }}$ & $\uparrow$ & Taxvig et al. (2007) \\
\hline \multicolumn{6}{|l|}{ Pesticides } \\
\hline Triadimefon & $\sim 114$ & $3^{\text {Increased }}$ & $\mathrm{x}$ & $\mathrm{x}$ & Goetz et al. (2007) \\
\hline Mancozeb & 25 & n.e. & n.e. & n.e. & Hass et al. (2012) \\
\hline \multirow[t]{6}{*}{ Vinclozolin } & 12 & n.e. & n.e. & n.e. & Colbert et al. (2005) \\
\hline & $50-60$ & $21^{\text {Matsuura }}$ & $9-21$ & n.e. ${ }^{\text {Matsuura }}$ & $\begin{array}{l}\text { Christiansen et al. (2009) and } \\
\text { Matsuura et al. (2005a) }\end{array}$ \\
\hline & $\sim 100$ & 28 & 22 & $\mathrm{x}$ & Schneider et al. (2011) \\
\hline & 100 & 28 & $\mathrm{x}$ & $\mathrm{x}$ & Ostby et al. (1999) \\
\hline & 160 & $\mathrm{x}$ & 35 & $\mathrm{x}$ & Hass et al. (2007) \\
\hline & 200 & $46-56$ & $\mathrm{x}$ & $(\downarrow)^{\text {Gray }}$ & $\begin{array}{l}\text { Gray et al. (1994) and Wolf } \\
\text { et al. (2004) }\end{array}$ \\
\hline \multirow[t]{3}{*}{ Procymidone } & 50 & 10 & 9 & n.e. & Hass et al. (2012) \\
\hline & 100 & 24 & n.e. & $\mathrm{x}$ & Wolf et al. (1999) \\
\hline & 150 & $\mathrm{x}$ & 37 & $\mathrm{x}$ & Hass et al. (2007) \\
\hline
\end{tabular}


Table 2 (continued)

\begin{tabular}{|c|c|c|c|c|c|}
\hline Substance & $\begin{array}{l}\text { Dose at max } \\
\text { effects ( } \mathrm{mg} / \mathrm{kg} \text { bw/ } \\
\text { day) }\end{array}$ & Male AGD max effect (\% shorter) & $\begin{array}{l}\text { Male AGDi max } \\
\text { effect (\% shorter) }\end{array}$ & $\begin{array}{l}\text { Female AGD } \\
\text { or AGDi }(\uparrow / \downarrow)\end{array}$ & References \\
\hline \multirow[t]{2}{*}{ Linuron } & 50 & $8^{\text {Not sig. in } 2000}$ & $\mathrm{x}$ & n.e. ${ }^{2002}$ & $\begin{array}{l}\text { McIntyre et al. (2002) and } \\
\text { McIntyre et al. (2000) }\end{array}$ \\
\hline & $75-100$ & $25-31$ & $\mathrm{x}$ & $\mathrm{x}$ & $\begin{array}{l}\text { Hotchkiss et al. (2004) and Wolf } \\
\text { et al. (1999) }\end{array}$ \\
\hline \multirow[t]{2}{*}{$p, p^{\prime}-\mathrm{DDE}$} & 100 & $6-9$ & $\mathrm{x}$ & $\mathrm{x}$ & Wolf et al. (1999) \\
\hline & $50-200$ & $\mathrm{x}$ & 11 (AGD/crown-rump length) & $\mathrm{x}$ & Loeffler and Peterson (1999) \\
\hline Fenitrothion & 25 & 16 & $\mathrm{x}$ & n.e. & Turner et al. (2002) \\
\hline Lindane & $\sim 16$ & n.e. & n.e. & $(\downarrow)$ & Matsuura et al. (2005b) \\
\hline \multicolumn{6}{|l|}{ UV filters } \\
\hline Benzophenone & $(\sim 130)$ & n.e. & n.e. & $\downarrow$ & Hoshino et al. (2005b) \\
\hline HBM & $(\sim 3250)$ & $\mathrm{x}$ & n.e. & n.e. & Nakamura et al. (2015) \\
\hline $\mathrm{OMC}$ & $(1000)$ & n.e. & n.e. & n.e. & Axelstad et al. (2011) \\
\hline \multicolumn{6}{|l|}{ Preservative } \\
\hline \multirow[t]{3}{*}{ Butylparaben } & 500 & 7 & 6 & $\downarrow$ & Boberg et al. (2016) \\
\hline & 600 & n.e. & n.e. & n.e. & Boberg et al. (2008) \\
\hline & 1000 & 16 & $\mathrm{x}$ & $\mathrm{x}$ & Zhang et al. (2014) \\
\hline \multicolumn{6}{|l|}{ Plastic additive } \\
\hline \multirow[t]{3}{*}{ Bisphenol A } & 0.25 & 7 & $\mathrm{x}$ & $\downarrow$ & Christiansen et al. (2014) \\
\hline & $(0.0025-50)$ & n.e. & n.e. (Ferguson, Tinwell) & $\begin{array}{l}\text { n.e. } \\
\text { Tinwell }\end{array}$ & $\begin{array}{l}\text { Ferguson et al. (2011), } \\
\text { Howdeshell et al. (2008) and } \\
\text { Tinwell et al. (2002) }\end{array}$ \\
\hline & $(5-385)$ & n.e. & $\mathrm{x}$ & n.e. & Takagi et al. (2004) \\
\hline Nonylphenol & $(\sim 250)$ & n.e. & n.e. & $\downarrow$ & Takagi et al. (2004) \\
\hline Genistein & $\sim 67$ & n.e. & $\mathrm{x}$ & n.e. & Masutomi et al. (2003) \\
\hline \multicolumn{6}{|l|}{ Other } \\
\hline TCDD & 0.1 & $6-12^{\text {Not sig. when BW or CR length taken into account }}$ & $\mathrm{x}$ & $\mathrm{x}$ & $\begin{array}{l}\text { Bjerke and Peterson (1994) and } \\
\text { Gray et al. (1995) }\end{array}$ \\
\hline
\end{tabular}

AGD data after in utero exposure to various substances and the dose at which maximum shorter mean AGD was observed. In many instances, percentage shorter AGD was estimated from published graphs, as raw data were not available. A more complete compilation of data is found in Suppl. Table S1

$x$ not assessed, n.e. no effect, $\uparrow$ longer female AGD or AGDi, $\downarrow$ shorter female AGD or AGDi, DDE DDT metabolite, dichloro-diphenyl-dichloroethylene, TCDD 2,3,7,8-tetrachlorodibenzo-p-dioxin, HBM 2-hydroxy-4-methoxybenzone, $O M C$ octyl methoxycinnamate

${ }^{a}$ Non-monotonic (low-dose) effect

cryptorchidism (Jain and Singal 2013; Jiang et al. 2015a), penile length (Alaee et al. 2014; Thankamony et al. 2014), and sperm quality (Eisenberg et al. 2012; Mendiola et al. 2011). Together, these observations fit the model of a common 'fetal origin of disease', with androgen disruption at the root of the problem. However, they cannot provide definite proof for cause-effect relationships. There is also the complications of accounting for genetic variations of the fetus or maternal characteristics such as parity, factors that themselves can influence the AGD (Barrett et al. 2014; Eisenberg et al. 2013). This ultimately means that two individuals being exposed to the same chemicals could respond differently and display variable degree of changes to the AGD. Because of all these complexities with interpreting human data, the rodent models can be used to provide more robust causative evidence.

\section{AGD measurements in rodent studies}

In rats, a short AGD in male offspring after fetal exposure to anti-androgenic compounds often correlates with various reproductive disorders (Bowman et al. 2003; Christiansen et al. 2008; Welsh et al. 2008, 2010). There is evidence to suggest that the more pronounced the effect on the AGD, the more likely additional reproductive defects such as genital malformations are found (Christiansen et al. 2008). However, there is not always a clear correlation between the severity of AGD effects and severity or frequency of other reproductive malformations, such that AGD cannot always stand on its own in the prediction of perceived antiandrogenic effects.

High-exposure studies have reported on male pups with 'female-like' AGD, where male AGD in exposed offspring is 


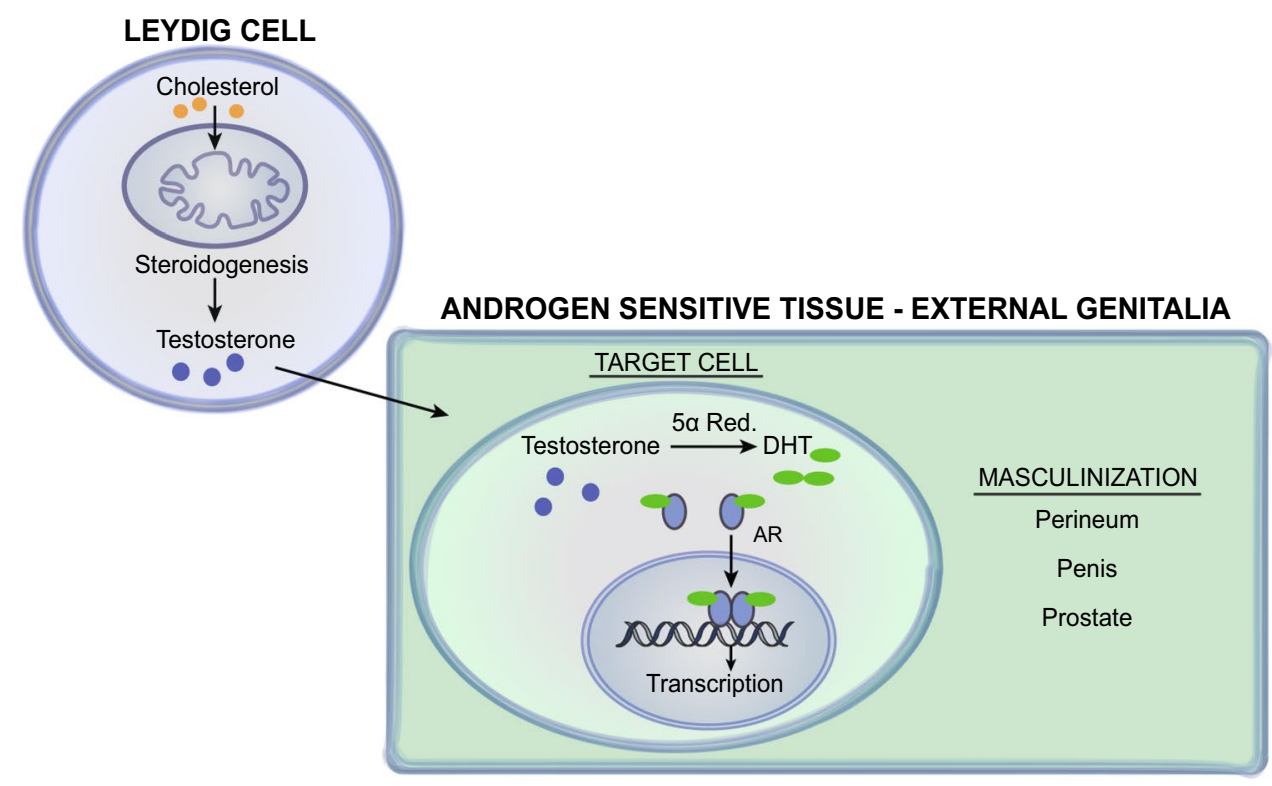

Fig. 2 Androgen signaling cascade required for fetal masculinization. Testosterone is synthesized in the testicular Leydig cells from precursor cholesterol. Testosterone is then secreted into the body circulation, where it acts on different androgen-sensitive tissues and organs. Differentiation of the internal male reproductive accessory organs (e.g., epididymis) is stimulated by testosterone, whereas external gen-

close to $50 \%$ that of control males. This does not only make the sex of the offspring difficult to determine (Christiansen et al. 2010; Hass et al. 2007; Ostby et al. 1999; Parks et al. 2000), but also result in additional phenotypes including nipple retention, genital malformations, and reduced reproductive organ weights (Bowman et al. 2003; Christiansen et al. 2008; Welsh et al. 2008, 2010). These reproductive phenotypes are all, at least to some degree, under androgen control during fetal development, making AGD a potentially robust marker for anti-androgenic effects.

\section{AGD in animal toxicity studies: phthalates}

The group of compounds most frequently reported to affect male AGD is the phthalate esters. As summarized in Table 1, many different phthalates have been tested in rats, with dibutyl phthalate (DBP) and diethylhexyl phthalate (DEHP) being the most prevalent. From an early rat study on DEHP showing testicular toxicity (Gray et al. 1977) and structure-activity relationships suggesting linear side-chain esters of 4-6 carbons to be of specific concern (Foster et al. 1980), numerous toxicity studies on phthalates followed, providing increasing evidence for what later has been termed the 'phthalate syndrome' [(Foster 2006) and Table 1].

Fetal exposure to certain phthalates (chain length $\mathrm{C} 4-\mathrm{C} 6$ ) results in a short AGD in rat male offspring, without any significant effect on female AGD (Table 1). It is, for the most italia and perineum requires the local conversion of testosterone into DHT by the enzyme $5 \alpha$-Reductase. DHT can bind to the Androgen receptor (AR) which subsequently locates to the nucleus and regulate expression of target genes. Cell-dependent regulatory signaling pathways are activated and regulate the differentiation into specialized tissues and organs (e.g., LABC complex and external genitalia)

part, a dose-dependent effect, where increasing dose levels result in progressively shorter AGD. Notably, the magnitude of AGD effects can differ greatly between studies, probably influenced by parameters such as rat strain, group size, or method used for AGD measurements. Body weights may also influence AGD measurements, but are unfortunately not always accounted for. In developmental toxicity studies, the offspring's body weight is in fact frequently affected, particularly at higher exposure levels (Gallavan et al. 1999). Since the AGD correlates with the size of the fetus or newborn pup, body weight should ideally be accounted for by calculating the AGDi, or by including body weight as a covariate in the statistical analysis. Unfortunately, this is not always done, as indicated in Tables 1 and 2. This means that a significantly short AGD in many instances may not be bona fide feminization effect, but rather a readout of stunted growth. To remedy this problem for risk-assessment purposes, OECD test guidelines and guidance documents stipulate that bodyweight measurements must be included alongside AGD measurements (guidance documents 151 and 43), as discussed in "AGD measurements in regulatory toxicology".

From the studies listed in Table 1, the most pronounced effect on AGD was seen for DBP at a dose of $1500 \mathrm{mg} /$ $\mathrm{kg} / \mathrm{day}$. At this high perinatal exposure level, the average male AGD was $48 \%$ shorter than normal, but when accounting for pup body weight, the adjusted value (AGDi) was 
$26 \%$ shorter than normal (Ema et al. 2000). With this in mind, most of the remaining studies investigating the antiandrogenic phthalates have shown maximum shorter male AGD of between 15 and 30\% at exposure doses between 100 and $500 \mathrm{mg} / \mathrm{kg} /$ day (Table 1). Thus, the active phthalates typically show marked effects on AGD, but rarely complete feminization (i.e., not comparable to female AGD), in a dose-dependent manner. These are high doses that also cause other reproductive disorders and in some cases show signs of systemic toxicity, reduced body weight, or increased liver weights. At lower exposure levels, these same phthalates typically cause less severe, yet statistically significant shorter male AGD, whereas other adverse effects on reproductive organs or systemic toxicity are less prevalent. Hence, a short AGD is often the most prevalent adverse effect observed at the lowest dose, supporting the use of AGD as a sensitive biomarker for these compounds.

Rat Leydig cells appear more sensitive to phthalate disruption than mouse and human Leydig cells (Svechnikov et al. 2016). For instance, the phthalate esters DEHP, MEHP, and DBP reportedly elevate testosterone levels in mice at early developmental stages, but suppress at late gestation, whereas no effects are observed in human fetal testis explants, with or without luteinizing hormone (LH) stimulation. Yet, in cultured mouse Leydig cells, MEHP can both inhibit and stimulate steroidogenesis depending on cell line (Svechnikov et al. 2016). These observations indicate that at least in some instances, disruption to testosterone output is not simply caused by direct disruption of steroidogenesis, or Leydig cells, but likely also includes endocrine signaling networks such as pituitary hormones. The implication of these discrepancies for using AGD as a biomarker for antiandrogenic effects remains uncertain. The best argument would be that since the rat seems to be the most sensitive model, it has the highest potential for safeguarding humans against detrimental effects in the wake of intrauterine exposures. However, more detailed knowledge about molecular events that are both similar and different between species is needed to devise the best test strategies for the future. The human relevance of rodent AGD data could then potentially be confirmed by testing chemicals in human-based cell and tissue systems.

\section{AGD in animal toxicity studies: miscellaneous compounds}

As summarized in Table 2, various substances from diverse chemical classes can affect the AGD in rat offspring. These include compounds with a clear anti-androgenic mode of action that cause even more severe effects on AGD than the potent anti-androgenic phthalates.

Prenatal exposure to high doses of certain AR antagonists completely feminizes the male pup AGD to 50\% that of control males. This is the case for the pesticide procymidone, vinclozolin, and the non-steroidal prostate cancer drug flutamide (Christiansen et al. 2008; Hass et al. 2007; Ostby et al. 1999; Parks et al. 2000). After exposure to these compounds, the male offspring also displays an increased rate of nipple retention, high incidence of genital malformations, and severely reduced male reproductive organ weights (Bowman et al. 2003; Christiansen et al. 2008; Welsh et al. 2008, 2010). As shown in Table 2, compounds such as the pesticide linuron, or the drugs finasteride and acetylsalicylic acid have also been shown to induce discernibly shorter male AGD (maximum response in the range of 31-38\%). Yet, for the majority of the tested chemicals, the maximum effect on AGD in males ranges from 5 to $15 \%$ shorter than normal. Of note, for several of the listed compounds the relationship between chemical exposure and AGD does not always follow a continuous pattern, where reduction in the AGD index is proportional to exposure levels, or concomitant reproductive abnormalities.

Fetal exposure to both the antimicrobial preservative butyl paraben (Boberg et al. 2016; Zhang et al. 2014) and the industrial plasticizer bisphenol A (Christiansen et al. 2014) has been shown to shorten the male AGD around 7-16\% in the male offspring, albeit there are studies reporting no effects on AGD for both butyl paraben (Boberg et al. 2008) and bisphenol A (Ferguson et al. 2011; Howdeshell et al. 2008; Takagi et al. 2004; Tinwell et al. 2002). In the cases where short AGD was observed with these compounds, clear effects on nipple retention or genital malformations were rarely seen. On the other hand, decreased sperm count or affected prostate development were observed, as were disrupted mammary glands in female offspring (Boberg et al. 2016; Hass et al. 2016; Mandrup et al. 2016). The intuitively appealing explanation for these discrepancies in phenotypic manifestations is that the latter compounds are considered mainly estrogenic. However, they also display weak antiandrogenic potential in vitro (Chen et al. 2007; Reif et al. 2010; Rosenmai et al. 2014; Satoh et al. 2005) and show effect in several in vitro toxicity assays for other mechanisms of action according to Toxicity Forecast [ToxCast; a program developed by the US Environmental Protection Agency to predict hazards and prioritize toxicity testing of environmental chemicals (Dix et al. 2007)]. This leaves the question of whether this small effect on AGD is the result of a weak anti-androgenic or an estrogenic effect, or yet another mechanism of action.

Fetal exposure to the estrogenic compound ethinyl estradiol does not seem to affect AGD in male offspring (Ferguson et al. 2012; Howdeshell et al. 2008; Mandrup et al. 2013), which then argue against the observed effect on male AGD following exposure to butyl paraben or BPA being estrogenic. It appears more likely that there are some weaker anti-androgenic effects exerted by these compounds 
that do not increase significantly in efficacy at increasing doses. Another explanation could be lent from observations that estrogenic compounds can reduce the ability of Leydig cells to synthesize testosterone, as reviewed elsewhere (Svechnikov et al. 2010). A recent study where mice were exposed to diethylstilbestrol (DES) also resulted in a short AGD in male offspring, again hypothesized to be caused by reduced testosterone production (Stewart et al. 2018). This is in agreement with what has been observed in rats following exposure to high doses of estrogens, where AR expression is lost in all tissues that show 'anti-androgenic' effects, as well as a reduction in Leydig cell numbers (Williams et al. 2001). Nevertheless, more mechanistic insight is required to fully explain how estrogenic compounds give rise to seemingly anti-androgenic effects.

Another group of chemicals that can elicit effects on reproductive development, including AGD, is the azole fungicides. They are used by both the medical and agricultural industries for their anti-fungal properties. They can, however, provoke side effects in humans and are known to primarily interfere with CYP-family enzymes (Ashley et al. 2006), but also nuclear receptors (Dreisig et al. 2013). As shown in Table 2, there are six azoles that in some studies have been shown to affect the AGD in rats: the drug ketoconazole, and the pesticides epoxiconazole, myclobutanil, prochloraz, propiconazole, and tebuconazole. At tested doses, they do not cause large changes to AGD, but strikingly, many of them cause longer rather than shorter AGD in male offspring. This is not the case for ketoconazole, however, where fetal exposure to $50 \mathrm{mg} / \mathrm{kg}$ resulted in around 8-11\% shorter male AGD (Taxvig et al. 2008). Notably, a contradictory study has reported no effect on AGD after exposure to ketoconazole at a similarly high dose (Wolf et al. 1999).

Prochloraz is an imidazole fungicide that can cause various adverse effects in rat fetuses at high doses. Regarding reproductive effects, prochloraz exposure can induce nipple retention in male offspring (Christiansen et al. 2009; Vinggaard et al. 2005), whereas effects on AGD are conflicting between studies. If taking birth-weight into account, there were no significant effects on male AGD at doses similar to those causing nipple retention $(25-150 \mathrm{mg} / \mathrm{kg}$ ) (Christiansen et al. 2009; Melching-Kollmuss et al. 2017; Noriega et al. 2005; Vinggaard et al. 2005). Another study reported around $10 \%$ shorter male AGD after fetal exposure to high doses of prochloraz concomitant with nipple retention at the same doses (Laier et al. 2006). Screening studies have shown that prochloraz can provoke multiple mechanisms of action in vitro, as it antagonizes the androgen and the estrogen receptor, agonizes the Ah receptor, and inhibits aromatase activity (Vinggaard et al. 2006). Whether or not all these mechanism are activated in vivo, and what effects this would have on the developing fetus, remains to be properly clarified.

Exposure to myclobutanil, propioconazole, and tebuconazole can all seemingly induce longer AGD in male offspring, whereas with epoxiconazole, the picture is less clear with only weak indications that it may affect AGD (Goetz et al. 2007; Hass et al. 2012; Taxvig et al. 2007). By what mechanisms this occur remains unclear. Taken together, however, the azole fungicides seem to elicit different effects on the developing fetus, resulting in effect outcomes not readily explained due to our limited knowledge about mechanisms and modalities, which should be a focus area for future studies.

\section{Note on mild analgesics and their endocrine disrupting properties}

Non-steroidal anti-inflammatory drugs (NSAIDs) and paracetamol/acetaminophen represent a group of mild analgesics suggested to have endocrine disrupting properties. As recently reviewed (Kristensen et al. 2016), their use across the world has risen dramatically in recent years. Herein, we will not discuss in great detail the potential endocrine effects from the analgesics, but highlight studies where effects on AGD have been reported.

Fetal exposure to therapeutically relevant doses of paracetamol can result in 5-10\% reduction in male rat AGDi (Kristensen et al. 2011). Another study using a similar high dose and exposure regimen failed to show a statistically significant change to male AGDi, but here, significant effects on nipple retention and reduction in LABC muscle complex weight were observed (Axelstad et al. 2014). Effects on AGD have also been observed in mice after in utero exposure to mild analgesics, and already in 1986, it was shown that male fetuses exposed to aspirin or indomethacin could present with shorter than normal AGD (Gupta and Goldman 1986). More recently, exposure to both aniline (which is metabolized to paracetamol in vivo) and paracetamol during pregnancy resulted in short AGD in male offspring (Holm et al. 2015). Although these studies strongly suggest that the mild analgesics act as anti-androgenic agents in the male fetuses, there are still not enough mechanistic studies available that convincingly support this conclusion.

\section{Is AGD a useful biomarker for female reproduction?}

In females, a longer AGD is considered a masculinization effect, something that would result from the presence of excess androgen levels or ectopic activation of AR. For example, longer than normal female AGD is associated with elevated testosterone levels (Mira-Escolano et al. 2014), exemplified by daughters born of women with polycystic ovarian syndrome (Barrett et al. 2018; Wu et al. 2017). 
These clinical observations are further supported by rat studies (Hotchkiss et al. 2007; Ostby and Gray 2004; Ramezani Tehrani et al. 2014; Wolf et al. 2002), and are in line with what we know about how androgens masculinize fetal tissues. However, other mechanisms have also been proposed to underpin masculinization of female fetuses, for instance, ectopic activation of the progesterone receptor (PR).

The fungicide vinclozolin has been suggested to masculinize mouse female fetuses by activation of the PR, further supported by the fact that the synthetic progesterone medroxyprogesterone acetate also masculinizes the female offspring (Buckley et al. 2006). Notably, fetal exposure in rats had no significant effect on female AGD (Hass et al. 2007). Nevertheless, although synthetic progesterones can activate the PR, many synthetic progestins such as medroxyprogesterone also targets other nuclear receptors and can give rise to many off-target effects (Kuhl 2005). For instance, progestins were widely used to prevent miscarriage in the $1950 \mathrm{~s}$ and $60 \mathrm{~s}$, but proved to masculinize the external genitalia of the female offspring (Money and Mathews 1982), and initially referred to as progestin-induced hermaphroditism (Wilkins et al. 1958). Even if these effects seem to be driven by PR-mediated signaling, it cannot be excluded that androgenic modes of action are involved. Not only are several progestins, including medroxyprogesterone, androgenic (Kuhl 2005), but androgen levels can seemingly also be elevated by high levels of progesterone, ultimately giving rise to androgenic effects (Auchus and Chang 2010).

Female rats exposed to the azole fungicide prochloraz present with longer AGD at birth, concomitant with elevated progesterone levels (Laier et al. 2006; Melching-Kollmuss et al. 2017). Prochloraz can induce progesterone synthesis in vitro by CYP17 inhibition at concentrations above $10 \mathrm{nM}$ (Dreisig et al. 2013), a mechanism confirmed in vivo, where fetal plasma concentrations were measured at $24 \mathrm{nM}$ following maternal exposure to $150 \mathrm{mg} / \mathrm{kg}$ bw/day of prochloraz (Laier et al. 2006). Although this does not prove that progesterone was acting via the PR to induce masculinization, androgen levels were not elevated in the same animals and hence suggest that this is an alternative mechanism, since azoles themselves do not seem to activate the AR. A definitive answer remains elusive, however, and much work remains to be done on azoles to characterize their sometimes perplexing modes of action.

Estrogens can seemingly also cause longer AGD in females. Although fetal exposure to ethinyl estradiol does not affect male AGD in rats, female offspring can present with longer AGD following exposure to supra-physiologically doses (Casanova et al. 1999; Delclos et al. 2009; Mandrup et al. 2013; NTP 2010; Ryan et al. 2010; Sawaki et al. 2003). Immediately, this effect seems counter-intuitive; however, very high doses of steroidal estrogens can agonize the AR (Vinggaard et al. 1999), which suggests that the effects are driven by androgen action rather than being estrogenic.
There are also examples, where female AGD is shorter than normal following in utero exposure, observations that evoke more questions than answers. The types of compounds capable of shortening female AGD in rodent are also variable and include bisphenol A (Christiansen et al. 2014), butyl paraben (Boberg et al. 2016), ketoconazole (Taxvig et al. 2008), paracetamol (Holm et al. 2016), as well as di- $n$-hexyl phthalate and dicyclohexyl phthalate (Aydoğan Ahbab and Barlas 2015). These studies are not covered in detail herein, and thus not presented with proper weight of evidence as yet any plausible mechanisms- or modes of action are lacking. It would, however, be of great interest to design studies specifically to answer such questions, as they may reveal insights of value to perineal development more broadly.

\section{AGD measurements in regulatory toxicology}

\section{AGD in chemical risk assessment}

Within a regulatory context, AGD measurements are mandatory to perform at either gestational days 20-21 or postnatal days $0-4$ in several OECD test guidelines used to test for developmental and reproductive toxicity in chemical risk assessment. These guidelines include the extended one generation study (TG 443), the two reproductive toxicity screening studies (TG 421/422) and the newly updated TG 414 Developmental toxicity study (OECD 2012, 2016a, b, 2018). The OECD guidance documents (OECD GD 43 and GD 151), which guides the interpretation of these guidelines, states that "A statistically significant change in AGD that cannot be explained by the size of the animal indicates effects of the exposure and should be considered in setting the NOAEL (No Observed Adverse Effect Level)" (OECD 2008, 2013). This means that, when a statistically significant shorter AGD in male rat offspring is considered the critical effect, a NOAEL can be based on this information and used as the point of departure for setting safe exposure levels for humans. Since AGD measurements will be included as an endpoint when performing almost all future regulatory studies investigating developmental and reproductive toxicity, it will improve on the sensitivity for identifying endocrine disruptors and developmental toxicants in mammals. In addition, this inclusion will generate much data, which will contribute to more thorough evaluations of substances and information pertaining to their modes of action.

\section{Other morphological biomarkers to support AGD}

Nipples and mammary glands originate from bipotential structures that develop differentially between the sexes in response to specific molecular cues. In humans, both sexes are born with a pair of nipples and breast development in 
girls is only initiated during puberty. In rats, the situation is somewhat different, as only the females retain their nipples; postnatal males only possess rudimentary structures (Kratochwil 1971).

In the developing male rodent, the presence of DHT causes regression, or apoptosis of the nipple anlagen (Imperato-McGinley et al. 1986). This process is blocked by fetal exposure to anti-androgens, and these male offspring subsequently display nipples similarly to their female littermates. Therefore, nipple retention in male pups is used alongside AGD as a morphometric marker of impaired androgen action. Although this morphological phenomenon does not occur in humans, it can, nevertheless, be used to predict anti-androgenic effects of chemicals. In other words, the fact that nipples are retained in exposed male rat offspring can be used to predict reproductive disorders caused by chemical exposures, even though nipples do not regress in human males. Whether AGD or nipple retention possess similar sensitivity, as was recently shown for an 18-chemical mixture of anti-androgens (Conley et al. 2018), or if one of the endpoints is more sensitive than the other, seems to depend on what chemical is being tested. Therefore, inclusion of both AGD and nipple retention in reproductive toxicity studies, in a weight-of-evidence manner, can significantly improve on the assessment of potential EDCs (OECD 2015). Nipple retention is also mandatory to assess in three separate OECD test guidelines (TG 443, TG 421/422).

\section{Conclusions and perspectives}

AGD has emerged a useful biomarker to detect fetal androgen insufficiency and is now applied in regulatory testing strategies for detecting endocrine disrupting effects. Its utility in a clinical setting is less defined, but it has received more traction in the last few years. It is our conviction that it will remain a standard retrospective biomarker in rodent toxicity studies and risk assessment. In humans, it will increasingly serve as a prospective biomarker, where a shorter than normal AGD in male offspring will be a warning flag for future reproductive complications, not least fertility issues. For this to fully eventuate, however, much more research focusing on answering many knowledge gaps is required. To this end, we would emphasize four areas that we believe should be focused on in the near future.

First, more efforts should be channelled into characterizing the morphoregulatory pathways of perineal development. Although the current dogma stipulates that the length of the AGD is controlled by the level of androgen action during the 'masculinization programming window', other regulatory pathways also seem to play a role, at the very least as effect-outcome modifiers.
Second, there is a need to better define the relationship between anti-androgenic effects and the length of the male AGD, both in rodents and humans. Should we rely purely on 'statistically significant' differences, or should a minimum percentage shorter than control mean be defined? And more importantly, can the magnitude of shortening be used to define magnitude of lost androgen action or future risk of contracting reproductive disease?

Third, to what extent can AGD measurements be used as a stand-alone biomarker to detect anti-androgenic effects in toxicity studies, and where do we need to supplement with additional effect measures? In a weight-of-evidence approach —which is currently recommended-what other measurements should be included, and when? For these evaluations, there should also be stronger emphasis on effect doses and to what extend supra-high doses reliably recapitulates what occurs at more human relevant doses. This latter point seems more important in view of chemicals that do not result in clear monotonic dose-response relationships.

Fourth, can AGD measurements be used as a biomarker in females? Certain perturbations can affect female AGD in either direction, but what does a long or short AGD really measure in female offspring? And is it linked to adverse health effects later in life? Concerning a longer than normal AGD, it would most often, if not always, be a sign of masculinization effects comparable to those observed when female fetuses receives too much androgens. With a shorter AGD, however, the jury is still out.

Acknowledgements This work was partly funded by Grants from the Danish Food and Veterinary Agency and the Independent Research Fund Denmark (DFF-6108-00114).

\section{Compliance with ethical standards}

Conflict of interest The authors declare that they have no conflict of interest pertaining to this work.

Open Access This article is distributed under the terms of the Creative Commons Attribution 4.0 International License (http://creativeco mmons.org/licenses/by/4.0/), which permits unrestricted use, distribution, and reproduction in any medium, provided you give appropriate credit to the original author(s) and the source, provide a link to the Creative Commons license, and indicate if changes were made.

\section{References}

Adibi JJ, Lee MK, Naimi AI, Barrett E, Nguyen RH, Sathyanarayana S, Zhao Y, Thiet MP, Redmon JB, Swan SH (2015) Human chorionic gonadotropin partially mediates phthalate association with male and female anogenital distance. J Clin Endocrinol Metab 100(9):E1216-E1224. https://doi.org/10.1210/jc.2015-2370

Alaee E, Gharib MJ, Fouladinejad M (2014) Penile length and anogenital distance in male newborns from different Iranian ethnicities 
in golestan province. Iran Red Crescent Med J 16(12):e16729. https://doi.org/10.5812/ircmj.16729

Ashley ESD, Lewis R, Lewis JS, Martin C, Andes D (2006) Pharmacology of systemic antifungal agents. Clin Infect Dis 43(Supplement_1):S28-S39. https://doi.org/10.1086/504492

Auchus RJ, Chang AY (2010) 46, XX DSD: the masculinised female. Best Pract Res Clin Endocrinol Metab 24(2):219-242. https:// doi.org/10.1016/j.beem.2009.11.001

Axelstad M, Boberg J, Hougaard KS, Christiansen S, Jacobsen PR, Mandrup KR, Nellemann C, Lund SP, Hass U (2011) Effects of pre- and postnatal exposure to the UV-filter octyl methoxycinnamate $(\mathrm{OMC})$ on the reproductive, auditory and neurological development of rat offspring. Toxicol Appl Pharmacol 250(3):278-290. https://doi.org/10.1016/j.taap.2010.10.031

Axelstad M, Christiansen S, Boberg J, Scholze M, Jacobsen PR, Isling LK, Kortenkamp A, Hass U (2014) Mixtures of endocrinedisrupting contaminants induce adverse developmental effects in preweaning rats. Reproduction 147(4):489-501. https://doi. org/10.1530/REP-13-0447

Aydoğan Ahbab M, Barlas N (2015) Influence of in utero di- $n$-hexyl phthalate and dicyclohexyl phthalate on fetal testicular development in rats. Toxicol Lett 233(2):125-137. https://doi. org/10.1016/j.toxlet.2015.01.015

Barlow NJ, McIntyre BS, Foster PM (2004) Male reproductive tract lesions at 6,12 , and 18 months of age following in utero exposure to di(n-butyl) phthalate. Toxicol Pathol 32(1):79-90. https://doi. org/10.1080/01926230490265894

Barrett ES, Parlett LE, Redmon JB, Swan SH (2014) Evidence for sexually dimorphic associations between maternal characteristics and anogenital distance, a marker of reproductive development. Am J Epidemiol 179(1):57-66. https://doi.org/10.1093/ aje/kwt220

Barrett ES, Hoeger KM, Sathyanarayana S, Abbott DH, Redmon JB, Nguyen RHN, Swan SH (2018) Anogenital distance in newborn daughters of women with polycystic ovary syndrome indicates fetal testosterone exposure. J Dev Orig Health Dis 9(3):307-314. https://doi.org/10.1017/S2040174417001118

Behringer RR (1994) The in vivo roles of müllerian-inhibiting substance. Curr Top Dev Biol 29:171-187. https://doi. org/10.1016/S0070-2153(08)60550-5

Bjerke DL, Peterson RE (1994) Reproductive toxicity of 2,3,7,8-tetrachlorodibenzo- $p$-dioxin in male rats: different effects of in utero versus lactational exposure. Toxicol Appl Pharmacol 127(2):241-249. https://doi.org/10.1006/taap.1994.1158

Boberg J, Metzdorff S, Wortziger R, Axelstad M, Brokken L, Vinggaard AM, Dalgaard M, Nellemann C (2008) Impact of diisobutyl phthalate and other PPAR agonists on steroidogenesis and plasma insulin and leptin levels in fetal rats. Toxicology 250(2-3):75-81. https://doi.org/10.1016/j.tox.2008.05.020

Boberg J, Christiansen S, Axelstad M, Kledal TS, Vinggaard AM, Dalgaard M, Nellemann C, Hass U (2011) Reproductive and behavioral effects of diisononyl phthalate (DINP) in perinatally exposed rats. Reprod Toxicol 31(2):200-209. https://doi. org/10.1016/j.reprotox.2010.11.001

Boberg J, Axelstad M, Svingen T, Mandrup K, Christiansen S, Vinggaard AM, Hass U (2016) Multiple endocrine disrupting effects in rats perinatally exposed to butylparaben. Toxicol Sci 152(1):244-256. https://doi.org/10.1093/toxsci/kfw079

Borch J, Axelstad M, Vinggaard AM, Dalgaard M (2006) Diisobutyl phthalate has comparable anti-androgenic effects to di- $n$-butyl phthalate in fetal rat testis. Toxicol Lett 163(3):183-190. https ://doi.org/10.1016/j.toxlet.2005.10.020

Bornehag CG, Carlstedt F, Jönsson BA, Lindh CH, Jensen TK, Bodin A, Jonsson C, Janson S, Swan SH (2015) Prenatal phthalate exposures and anogenital distance in Swedish boys. Environ
Health Perspect 123(1):101-107. https://doi.org/10.1289/ ehp. 1408163

Bornman MS, Chevrier J, Rauch S, Crause M, Obida M, Sathyanarayana S, Barr DB, Eskenazi B (2016) Dichlorodiphenyltrichloroethane exposure and anogenital distance in the Venda Health Examination of Mothers, Babies and their Environment (VHEMBE) birth cohort study, South Africa. Andrology 4(4):608-615. https://doi.org/10.1111/andr.12235

Bowman CJ, Barlow NJ, Turner KJ, Wallace DG, Foster PM (2003) Effects of in utero exposure to finasteride on androgen-dependent reproductive development in the male rat. Toxicol Sci 74(2):393-406. https://doi.org/10.1093/toxsci/kfg128

Buckley J, Willingham E, Agras K, Baskin LS (2006) Embryonic exposure to the fungicide vinclozolin causes virilization of females and alteration of progesterone receptor expression in vivo: an experimental study in mice. Environ Health 5:4. https://doi.org/10.1186/1476-069X-5-4

Bustamante-Montes LP, Hernández-Valero MA, Flores-Pimentel D, García-Fábila M, Amaya-Chávez A, Barr DB, Borja-Aburto VH (2013) Prenatal exposure to phthalates is associated with decreased anogenital distance and penile size in male newborns. J Dev Orig Health Dis 4(4):300-306. https://doi. org/10.1017/S2040174413000172

Carruthers CM, Foster PM (2005) Critical window of male reproductive tract development in rats following gestational exposure to di- $n$-butyl phthalate. Birth Defects Res B Dev Reprod Toxicol 74(3):277-285. https://doi.org/10.1002/bdrb.20050

Casanova M, You L, Gaido KW, Archibegue-Engle S, Janszen DB, Heck HA (1999) Developmental effects of dietary phytoestrogens in Sprague-Dawley rats and interactions of genistein and daidzein with rat estrogen receptors alpha and beta in vitro. Toxicol Sci 51(2):236-244. https://doi.org/10.1093/toxsc i/51.2.236

Chen J, Ahn KC, Gee NA, Gee SJ, Hammock BD, Lasley BL (2007) Antiandrogenic properties of parabens and other phenolic containing small molecules in personal care products. Toxicol Appl Pharmacol 221(3):278-284. https://doi.org/10.1016/j. taap.2007.03.015

Christiansen S, Scholze M, Axelstad M, Boberg J, Kortenkamp A, Hass U (2008) Combined exposure to anti-androgens causes markedly increased frequencies of hypospadias in the rat. Int J Androl 31(2):241-248. https://doi.org/10.1111/j.1365-2605.2008.00866 . $\mathrm{x}$

Christiansen S, Scholze M, Dalgaard M, Vinggaard AM, Axelstad M, Kortenkamp A, Hass U (2009) Synergistic disruption of external male sex organ development by a mixture of four antiandrogens. Environ Health Perspect 117(12):1839-1846. https://doi. org/10.1289/ehp.0900689

Christiansen S, Boberg J, Axelstad M, Dalgaard M, Vinggaard AM, Metzdorff SB, Hass U (2010) Low-dose perinatal exposure to di(2-ethylhexyl) phthalate induces anti-androgenic effects in male rats. Reprod Toxicol 30(2):313-321. https://doi.org/10.1016/j. reprotox.2010.04.005

Christiansen S, Axelstad M, Boberg J, Vinggaard AM, Pedersen GA, Hass U (2014) Low-dose effects of bisphenol A on early sexual development in male and female rats. Reproduction 147(4):477487. https://doi.org/10.1530/REP-13-0377

Clewell RA, Thomas A, Wilson G, Creasy DM, Andersen ME (2013) A dose response study to assess effects after dietary administration of diisononyl phthalate (DINP) in gestation and lactation on male rat sexual development. Reprod Toxicol 35:70-80. https:// doi.org/10.1016/j.reprotox.2012.07.008

Colbert NK, Pelletier NC, Cote JM, Concannon JB, Jurdak NA, Minott SB, Markowski VP (2005) Perinatal exposure to low levels of the environmental antiandrogen vinclozolin alters sex-differentiated social play and sexual behaviors in the rat. Environ Health 
Perspect 113(6):700-707. https://doi.org/10.1016/10.1289/ ehp.7509

Conley JM, Lambright CS, Evans N, Cardon M, Furr J, Wilson VS, and Gray LE Jr (2018) Mixed "antiandrogenic" chemicals at low individual doses produce reproductive tract malformations in the male rat. Toxicol Sci 164:166-178. https://doi.org/10.1093/toxsc i/kfy069

Cox K, Kyriakou A, Amjad B, O'Toole S, Flett ME, Welsh M, Ahmed SF, Cascio S (2017) Shorter anogenital and anoscrotal distances correlate with the severity of hypospadias: a prospective study. J Pediatr Urol 13(1):57.e1-57.e5. https://doi.org/10.1016/j.jpuro 1.2016.08.006

Dalsager L, Christensen LE, Kongsholm MG, Kyhl HB, Nielsen F, Schoeters G, Jensen TK, Andersen HR (2018) Associations of maternal exposure to organophosphate and pyrethroid insecticides and the herbicide 2,4-D with birth outcomes and anogenital distance at 3 months in the Odense Child Cohort. Reprod Toxicol 76:53-62. https://doi.org/10.1016/j.reprotox.2017.12.008

de Mello Santos T, da Silveira LTR, Rinaldi JC, Scarano WR, Domeniconi RF (2017) Alterations in prostate morphogenesis in male rat offspring after maternal exposure to di- $n$-butyl-phthalate (DBP). Reprod Toxicol 69:254-264. https://doi.org/10.1016/j. reprotox.2017.03.010

Dean A, Sharpe RM (2013) Clinical review: anogenital distance or digit length ratio as measures of fetal androgen exposure: relationship to male reproductive development and its disorders. J Clin Endocrinol Metab 98(6):2230-2238. https://doi. org/10.1210/jc.2012-4057

Delclos KB, Weis CC, Bucci TJ, Olson G, Mellick P, Sadovova N, Latendresse JR, Thorn B, Newbold RR (2009) Overlapping but distinct effects of genistein and ethinyl estradiol (EE(2)) in female Sprague-Dawley rats in multigenerational reproductive and chronic toxicity studies. Reprod Toxicol 27(2):117-132. https://doi.org/10.1016/j.reprotox.2008.12.005

Dix DJ, Houck KA, Martin MT, Richard AM, Setzer RW, Kavlock RJ (2007) The ToxCast program for prioritizing toxicity testing of environmental chemicals. Toxicol Sci 95(1):5-12. https://doi. org/10.1093/toxsci/kfl103

Dreisig K, Taxvig C, Birkhøj Kjærstad M, Nellemann C, Hass U, Vinggaard AM (2013) Predictive value of cell assays for developmental toxicity and embryotoxicity of conazole fungicides. ALTEX 30(3):319-330. https://doi.org/10.14573/altex.2013.3.319

Eisenberg ML, Hsieh MH, Walters RC, Krasnow R, Lipshultz LI (2011) The relationship between anogenital distance, fatherhood, and fertility in adult men. PloS One 6(5):e18973. https://doi. org/10.1371/journal.pone.0018973

Eisenberg ML, Jensen TK, Walters RC, Skakkebaek NE, Lipshultz LI (2012) The relationship between anogenital distance and reproductive hormone levels in adult men. J Urol 187(2):594-598. https://doi.org/10.1016/j.juro.2011.10.041

Eisenberg ML, Hsieh TC, Pastuszak AW, McIntyre MG, Walters RC, Lamb DJ, Lipshultz LI (2013) The relationship between anogenital distance and the androgen receptor CAG repeat length. Asian J Androl 15(2):286-289. https://doi.org/10.1038/aja.2012.126

Ema M, Miyawaki E (2001) Adverse effects on development of the reproductive system in male offspring of rats given monobutyl phthalate, a metabolite of dibutyl phthalate, during late pregnancy. Reprod Toxicol 15(2):189-194. https://doi.org/10.1016/ S0890-6238(01)00111-3

Ema M, Miyawaki E (2002) Effects on development of the reproductive system in male offspring of rats given butyl benzyl phthalate during late pregnancy. Reprod Toxicol 16(1):71-76. https://doi. org/10.1016/S0890-6238(01)00200-3

Ema M, Miyawaki E, Kawashima K (1998) Further evaluation of developmental toxicity of di-n-butyl phthalate following administration during late pregnancy in rats. Toxicol Lett 98(12):87-93. https://doi.org/10.1016/S0378-4274(98)00107-6

Ema M, Miyawaki E, Kawashima K (2000) Critical period for adverse effects on development of reproductive system in male offspring of rats given di- $n$-butyl phthalate during late pregnancy. Toxicol Lett 111(3):271-278. https://doi.org/10.1016/S0378 -4274(99)00192-7

Ema M, Miyawaki E, Hirose A, Kamata E (2003) Decreased anogenital distance and increased incidence of undescended testes in fetuses of rats given monobenzyl phthalate, a major metabolite of butyl benzyl phthalate. Reprod Toxicol 17(4):407-412. https://doi. org/10.1016/S0890-6238(03)00037-6

Ferguson SA, Law CDJ, Abshire JS (2011) Developmental treatment with bisphenol A or ethinyl estradiol causes few alterations on early preweaning measures. Toxicol Sci 124(1):149-160. https ://doi.org/10.1093/toxsci/kfr201

Ferguson SA, Law CD, Abshire JS (2012) Developmental treatment with bisphenol A causes few alterations on measures of postweaning activity and learning. Neurotoxicol Teratol 34(6):598606. https://doi.org/10.1016/j.ntt.2012.09.006

Fisher BG, Thankamony A, Hughes IA, Ong KK, dunger DB, Acerini CL (2016) Prenatal paracetamol exposure is associated with shorter anogenital distance in male infants. Hum Reprod 31(11):2642-2650. https://doi.org/10.1093/humrep/dew196

Foster PM (2006) Disruption of reproductive development in male rat offspring following in utero exposure to phthalate esters. Int J Androl 29(1):140-147. https://doi.org/10.111 1/j.1365-2605.2005.00563.x

Foster PM, Harris MW (2005) Changes in androgen-mediated reproductive development in male rat offspring following exposure to a single oral dose of flutamide at different gestational ages. Toxicol Sci 85(2):1024-1032. https://doi.org/10.1093/toxsci/kfi159

Foster PM, Thomas LV, Cook MW, Gangolli SD (1980) Study of the testicular effects and changes in zinc excretion produced by some $n$-alkyl phthalates in the rat. Toxicol Appl Pharmacol 54(3):392398. https://doi.org/10.1016/0041-008X(80)90165-9

Gallavan RHJ, Holson JF, Stump DG, Knapp JF, Reynolds VL (1999) Interpreting the toxicologic significance of alterations in anogenital distance: potential for confounding effects of progeny body weights. Reprod Toxicol 13(5):383-390. https://doi.org/10.1016/ S0890-6238(99)00036-2

Gilboa Y, Perlman S, Kivilevitch Z, Messing B, Achiron R (2017) Prenatal anogenital distance is shorter in fetuses with hypospadias. J Ultrasound Med 36(1):175-182. https://doi.org/10.7863/ ultra.16.01006

Goetz AK, Ren H, Schmid JE, Blystone CR, Thillainadarajah I, Best DS, Nichols HP, Strader LF, Wolf DC, Narotsky MG, Rockett JC, Dix DJ (2007) Disruption of testosterone homeostasis as a mode of action for the reproductive toxicity of triazole fungicides in the male rat. Toxicol Sci 95(1):227-239. https://doi.org/10.1093/ toxsci/kfl124

Gray LE Jr, Kelce WR, Monosson E, Ostby JS, Birnbaum LS (1995) Exposure to TCDD during development permanently alters reproductive function in male Long Evans rats and hamsters: reduced ejaculated and epididymal sperm numbers and sex accessory gland weights in offspring with normal androgenic status. Toxicol Appl Pharmacol 131(1):108-118. https://doi. org/10.1006/taap.1995.1052

Gray LE Jr, Ostby J, Furr J, Price M, Veeramachaneni DN, Parks L (2000) Perinatal exposure to the phthalates DEHP, BBP, and DINP, but not DEP, DMP, or DOTP, alters sexual differentiation of the male rat. Toxicol Sci 58(2):350-365. https://doi. org/10.1093/toxsci/58.2.350

Gray TJ, Butterworth KR, Gaunt IF, Grasso GP, Gangolli SD (1977) Short-term toxicity study of di-(2-ethylhexyl) phthalate in rats. 
Food Cosmet Toxicol 15(5):389-399. https://doi.org/10.1016/ S0015-6264(77)80003-5

Gray LEJ, Ostby JS, Kelce WR (1994) Developmental effects of an environmental antiandrogen: the fungicide vinclozolin alters sex differentiation of the male rat. Toxicol Appl Pharmacol 129(1):46-52. https://doi.org/10.1006/taap.1994.1227

Gupta C, Goldman AS (1986) The arachidonic acid cascade is involved in the masculinizing action of testosterone on embryonic external genitalia in mice. Proc Natl Acad Sci USA 83(12):4346-4349. https://doi.org/10.1073/pnas.83.12.4346

Hass U, Scholze M, Christiansen S, Dalgaard M, Vinggaard AM, Axelstad M, Metzdorff SB, Kortenkamp A (2007) Combined exposure to anti-androgens exacerbates disruption of sexual differentiation in the rat. Environ Health Perspect 115(Suppl 1):122-128. https://doi.org/10.1289/ehp.9360

Hass U, Boberg J, Christiansen S, Jacobsen PR, Vinggaard AM, Taxvig C, Poulsen ME, Herrmann SS, Jensen BH, Petersen A, Clemmensen LH, Axelstad M (2012) Adverse effects on sexual development in rat offspring after low dose exposure to a mixture of endocrine disrupting pesticides. Reprod Toxicol 34(2):261-274. https://doi.org/10.1016/j.reprotox.2012.05.090

Hass U, Christiansen S, Boberg J, Rasmussen MG, Mandrup K, Axelstad M (2016) Low-dose effect of developmental bisphenol A exposure on sperm count and behaviour in rats. Andrology 4(4):594-607. https://doi.org/10.1111/andr.12176

Holm JB, Chalmey C, Modick H, Jensen LS, Dierkes G, Weiss T, Jensen BA, Norregard MM, Borkowski K, Styrishave B, Martin Koch H, Mazaud-Guittot S, Jegou B, Kristiansen K et al (2015) Aniline Is rapidly converted into paracetamol impairing male reproductive development. Toxicol Sci 148(1):288-298. https:// doi.org/10.1093/toxsci/kfv179

Holm JB, Mazaud-Guittot S, Danneskiold-Samsøe NB, Chalmey C, Jensen B, Nørregård MM, Hansen CH, Styrishave B, Svingen T, Vinggaard AM, Koch HM, Bowles J, Koopman P, Jégou B et al (2016) Intrauterine exposure to paracetamol and aniline impairs female reproductive development by reducing follicle reserves and fertility. Toxicol Sci 150(1):178-189. https://doi. org/10.1093/toxsci/kfv332

Hoshino N, Iwai M, Okazaki Y (2005a) A two-generation reproductive toxicity study of dicyclohexyl phthalate in rats. J Toxicol Sci 30(Spec No):79-96 https://doi.org/10.2131/jts.30.S79

Hoshino N, Tani E, Wako Y, Takahashi K (2005b) A two-generation reproductive toxicity study of benzophenone in rats. J Toxicol Sci 30(Spec No):5-20 https://doi.org/10.2131/jts.30.S5

Hotchkiss AK, Parks-Saldutti LG, Ostby JS, Lambright C, Furr J, Vandenbergh JG, Gray LEJ (2004) A mixture of the "antiandrogens" linuron and butyl benzyl phthalate alters sexual differentiation of the male rat in a cumulative fashion. Biol Reprod 71(6):18521861. https://doi.org/10.1095/biolreprod.104.031674

Hotchkiss AK, Lambright CS, Ostby JS, Parks-Saldutti L, Vandenbergh JG, Gray LEJ (2007) Prenatal testosterone exposure permanently masculinizes anogenital distance, nipple development, and reproductive tract morphology in female Sprague-Dawley rats. Toxicol Sci 96(2):335-345. https://doi.org/10.1093/toxsci/kfm002

Howdeshell KL, Furr J, Lambright CR, Rider CV, Wilson VS, Gray LE Jr (2007) Cumulative effects of dibutyl phthalate and diethylhexyl phthalate on male rat reproductive tract development: altered fetal steroid hormones and genes. Toxicol Sci 99(1):190202. https://doi.org/10.1093/toxsci/kfm069

Howdeshell KL, Furr J, Lambright CR, Wilson VS, Ryan BC, Gray LE Jr (2008) Gestational and lactational exposure to ethinyl estradiol, but not bisphenol A, decreases androgen-dependent reproductive organ weights and epididymal sperm abundance in the male long evans hooded rat. Toxicol Sci 102(2):371-382. https://doi.org/10.1093/toxsci/kfm306
Hsieh MH, Breyer BN, Eisenberg ML, Baskin LS (2008) Associations among hypospadias, cryptorchidism, anogenital distance, and endocrine disruption. Curr Urol Rep 9(2):137-142. https:// doi.org/10.1007/s11934-008-0025-0

Hsieh MH, Eisenberg ML, Hittelman AB, Wilson JM, Tasian GE, Baskin LS (2012) Caucasian male infants and boys with hypospadias exhibit reduced anogenital distance. Hum Reprod 27(6):1577-1580. https://doi.org/10.1093/humrep/des087

Imperato-McGinley J, Binienda Z, Gedney J, Vaughan EDJ (1986) Nipple differentiation in fetal male rats treated with an inhibitor of the enzyme 5 alpha-reductase: definition of a selective role for dihydrotestosterone. Endocrinology 118(1):132-137. https://doi. org/10.1210/endo-118-1-132

Ipulan LA, Suzuki K, Sakamoto Y, Murashima A, Imai Y, Omori A, Nakagata N, Nishinakamura R, Valasek P, Yamada G (2014) Nonmyocytic androgen receptor regulates the sexually dimorphic development of the embryonic bulbocavernosus muscle. Endocrinology 155(7):2467-2479. https://doi.org/10.1210/ en.2014-1008

Jain VG, Singal AK (2013) Shorter anogenital distance correlates with undescended testis: a detailed genital anthropometric analysis in human newborns. Hum Reprod 28(9):2343-2349. https://doi. org/10.1093/humrep/det286

Jarfelt K, Dalgaard M, Hass U, Borch J, Jacobsen H, Ladefoged O (2005) Antiandrogenic effects in male rats perinatally exposed to a mixture of di(2-ethylhexyl) phthalate and di(2-ethylhexyl) adipate. Reprod Toxicol 19(4):505-515. https://doi.org/10.1016/j. reprotox.2004.11.005

Jensen TK, Frederiksen H, Kyhl HB, Lassen TH, Swan SH, Bornehag CG, Skakkebaek NE, Main KM, Lind DV, Husby S, Andersson AM (2016) Prenatal exposure to phthalates and anogenital distance in male infants from a low-exposed Danish cohort (2010-2012). Environ Health Perspect 124(7):1107-1113. https ://doi.org/10.1289/ehp.1509870

Jiang J, Ma L, Yuan L, Wang X, Zhang W (2007) Study on developmental abnormalities in hypospadiac male rats induced by maternal exposure to di- $n$-butyl phthalate (DBP). Toxicol Appl Pharmacol 232(3):286-293. https://doi.org/10.1016/j.tox.2007.01.018

Jiang JT, Sun WL, Jing YF, Liu SB, Ma Z, Hong Y, Ma L, Qin C, Liu Q, Stratton HJ, Xia SJ (2011) Prenatal exposure to di-n-butyl phthalate induces anorectal malformations in male rat offspring. Toxicology 290(2-3):322-326. https://doi.org/10.1016/j. tox.2011.10.008

Jiang DP, Geng HQ, Lin HW, Yu X-n, Zhang XW, Yang SL, Wang S (2015a) Relationship between anogenital distance and cryptorchidism in human newborns. Zhonghua Nan Ke Xue 21(5):432-435

Jiang JT, Xu HL, Zhu YP, Wood K, Li EH, Sun WL, Yuan Q, Xu DL, Liu ZH, Zhao W, Xia SJ (2015b) Reduced Fgf10/Fgfr2 and androgen receptor (AR) in anorectal malformations male rats induced by di- $n$-butyl phthalate (DBP): a study on the local and systemic toxicology of DBP. Toxicology 338:77-85. https://doi. org/10.1016/j.tox.2015.10.006

Johansson HKL, Svingen T, Fowler PA, Vinggaard AM, Boberg J (2017) Environmental influences on ovarian dysgenesisdevelopmental windows sensitive to chemical exposures. Nat Rev Endocrinol 13(7):400-414. https://doi.org/10.1038/nrend o.2017.36

Josso N, Cate RL, Picard JY, Vigier B, di Clemente N, Wilson C, Imbeaud S, Pepinsky RB, Guerrier D, Boussin L, Legeai L, Carré-Eusèbe D (1993) Anti-müllerian hormone: the Jost factor. Recent Prog Horm Res 48:1-59

Jost A (1947) Recherches sur la differenciation sexuelle de l'embryon de lapin. Arch Anat Microsc Morphol Exp 36:271-315

Jost A (1953) Problems of fetal endocrinology: the gonadal and hypophyseal hormones. Recent Prog Horm Res 8:379-418 
Kita DH, Meyer KB, Venturelli AC, Adams R, Machado DL, Morais RN, Swan SH, Gennings C, Martino-Andrade AJ (2016) Manipulation of pre and postnatal androgen environments and anogenital distance in rats. Toxicology 368-369:152-161. https://doi. org/10.1016/j.tox.2016.08.021

Koopman P, Gubbay J, Vivian N, Goodfellow P, Lovell-Badge R (1991) Male development of chromosomally female mice transgenic for Sry. Nature 351(6322):117-121. https://doi.org/10.1038/35111 $7 \mathrm{a} 0$

Kratochwil K (1971) In vitro analysis of the hormonal basis for the sexual dimorphism in the embryonic development of the mouse mammary gland. J Embryol Exp Morphol 25(1):141-153

Kristensen DM, Hass U, Lesné L, Lottrup G, Jacobsen PR, DesdoitsLethimonier C, Boberg J, Petersen JH, Toppari J, Jensen TK, Brunak S, Skakkebaek NE, Nellemann C, Main KM et al (2011) Intrauterine exposure to mild analgesics is a risk factor for development of male reproductive disorders in human and rat. Hum Reprod 26(1):235-244. https://doi.org/10.1093/humrep/deq323

Kristensen DM, Mazaud-Guittot S, Gaudriault P, Lesné L, Serrano T, Main KM, Jégou B (2016) Analgesic use-prevalence, biomonitoring and endocrine and reproductive effects. Nat Rev Endocrinol 12(7):381-393. https://doi.org/10.1038/nrendo.2016.55

Kuhl H (2005) Pharmacology of estrogens and progestogens: influence of different routes of administration. Climacteric 8(Suppl 1):3-63. https://doi.org/10.1080/13697130500148875

Laier P, Metzdorff SB, Borch J, Hagen ML, Hass U, Christiansen S, Axelstad M, Kledal T, Dalgaard M, McKinnell C, Brokken LJ, Vinggaard AM (2006) Mechanisms of action underlying the antiandrogenic effects of the fungicide prochloraz. Toxicol Appl Pharmacol 213:2. https://doi.org/10.1016/j.taap.2005.10.013

Lassen TH, Frederiksen H, Kyhl HB, Swan SH, Main KM, Andersson AM, Lind DV, Husby S, Wohlfahrt-Veje C, Skakkebæk NE, Jensen TK (2016) Prenatal triclosan exposure and anthropometric measures including anogenital distance in Danish infants. Environ Health Perspect 124(8):1261-1268. https://doi. org/10.1289/ehp.1409637

Lee KY, Shibutani M, Takagi H, Kato N, Takigami S, Uneyama C, Hirose M (2004) Diverse developmental toxicity of di$n$-butyl phthalate in both sexes of rat offspring after maternal exposure during the period from late gestation through lactation. Toxicology 203(1-3):221-238. https://doi.org/10.1016/j. tox.2004.06.013

Li M, Qiu L, Zhang Y, Hua Y, Tu S, He Y, Wen S, Wang Q, Wei G (2013) Dose-related effect by maternal exposure to di(2-ethylhexyl) phthalate plasticizer on inducing hypospadiac male rats. Environ Toxicol Pharmacol 35(1):55-60. https://doi. org/10.1016/j.etap.2012.10.006

Li N, Chen X, Zhou X, Zhang W, Yuan J, Feng J (2015) The mechanism underlying dibutyl phthalate induced shortened anogenital distance and hypospadias in rats. J Pediatr Surg 50(12):20782083. https://doi.org/10.1016/j.jpedsurg.2015.08.046

Lin H, Lian QQ, Hu GX, Jin Y, Zhang Y, Hardy DO, Chen GR, Lu ZQ, Sottas CM, Hardy MP, Ge RS (2009) In utero and lactational exposures to diethylhexyl-phthalate affect two populations of Leydig cells in male Long-Evans rats. Biol Reprod 80(5):882888. https://doi.org/10.1095/biolreprod.108.072975

Lind DV, Main KM, Kyhl HB, Kristensen DM, Toppari J, Andersen HR, Andersen MS, Skakkebæk NE, Jensen TK (2017) Maternal use of mild analgesics during pregnancy associated with reduced anogenital distance in sons: a cohort study of 1027 mother-child pairs. Hum Reprod 32(1):223-231. https://doi.org/10.1093/ humrep/dew 285

Liu ZH, Li EH, Xu DL, Sun WL, Hong Y, Zhao W, Xia SJ, Jiang JT (2016) Genetic research and structural dysplasia assessment of anorectal malformations in neonatal male rats induced by di(n-butyl) phthalate. Environ Toxicol 31(3):261-268. https:// doi.org/10.1002/tox.22040

Loeffler IK, Peterson RE (1999) Interactive effects of TCDD and $p, p^{\prime}-$ DDE on male reproductive tract development in in utero and lactationally exposed rats. Toxicol Appl Pharmacol 154(1):28-39. https://doi.org/10.1006/taap.1998.8572

MacLean HE, Chiu WS, Notini AJ, Axell AM, Davey RA, McManus JF, Ma C, Plant DR, Lynch GS, Zajac JD (2008) Impaired skeletal muscle development and function in male, but not female, genomic androgen receptor knockout mice. FASEB J 22(8):2676-2689. https://doi.org/10.1096/fj.08-105726

MacLeod DJ, Sharpe RM, Welsh M, Fisken M, Scott HM, Hutchison GR, Drake AJ, van den Driesche S (2010) Androgen action in the masculinization programming window and development of male reproductive organs. Int J Androl 33(2):279-287. https:// doi.org/10.1111/j.1365-2605.2009.01005.x

Mammadov E, Uncu M, Dalkan C (2018) High prenatal exposure to bisphenol A reduces anogenital distance in healthy male newborns. J Clin Res Pediatr Endocrinol 10(1):25-29. https://doi. org/10.4274/jcrpe.4817

Mandrup K, Jacobsen PR, Isling LK, Axelstad M, Dreisig K, Hadrup N, Vinggaard AM, Hass U, Boberg J (2013) Effects of perinatal ethinyl estradiol exposure in male and female Wistar rats. Reprod Toxicol 42:180-191. https://doi.org/10.1016/j.repro tox.2013.09.001

Mandrup K, Boberg J, Isling LK, Christiansen S, Hass U (2016) Low-dose effects of bisphenol A on mammary gland development in rats. Andrology 4(4):673-683. https://doi.org/10.1111/ andr.12193

Marsee K, Woodruff TJ, Axelrad DA, Calafat AM, Swan SH (2006) Estimated daily phthalate exposures in a population of mothers of male infants exhibiting reduced anogenital distance. Environ Health Perspect 114(6):805-809. https://doi.org/10.1289/ ehp. 8663

Martino-Andrade AJ, Morais RN, Botelho GG, Muller G, Grande SW, Carpentieri GB, Leão GM, Dalsenter PR (2009) Coadministration of active phthalates results in disruption of foetal testicular function in rats. Int J Androl 32(6):704-712. https://doi.org/10. 1111/j.1365-2605.2008.00939.x

Masutomi N, Shibutani M, Takagi H, Uneyama C, Takahashi N, Hirose M (2003) Impact of dietary exposure to methoxychlor, genistein, or diisononyl phthalate during the perinatal period on the development of the rat endocrine/reproductive systems in later life. Toxicology 192(2-3):149-170. https://doi.org/10.1016/S0300 $-483 X(03) 00269-5$

Matsuura I, Saitoh T, Ashina M, Wako Y, Iwata H, Toyota N, Ishizuka Y, Namiki M, Hoshino N, Tsuchitani M (2005a) Evaluation of a two-generation reproduction toxicity study adding endpoints to detect endocrine disrupting activity using vinclozolin. J Toxicol Sci 30(Spec No):163-168 https://doi.org/10.2131/jts.30.S163

Matsuura I, Saitoh T, Tani E, Wako Y, Iwata H, Toyota N, Ishizuka Y, Namiki M, Hoshino N, Tsuchitani M, Ikeda Y (2005b) Evaluation of a two-generation reproduction toxicity study adding endpoints to detect endocrine disrupting activity using lindane. J Toxicol Sci 30(Spec No):135-161 https://doi.org/10.2131/jts.30. S135

McIntyre BS, Barlow NJ, Wallace DG, Maness SC, Gaido KW, Foster PM (2000) Effects of in utero exposure to linuron on androgendependent reproductive development in the male $\mathrm{Crl}: \mathrm{CD}(\mathrm{SD})$ BR rat. Toxicol Appl Pharmacol 167(2):87-99. https://doi. org/10.1006/taap.2000.8998

McIntyre BS, Barlow NJ, Foster PM (2001) Androgen-mediated development in male rat offspring exposed to flutamide in utero: permanence and correlation of early postnatal changes in anogenital distance and nipple retention with malformations in 
androgen-dependent tissues. Toxicol Sci 62(2):236-249. https ://doi.org/10.1093/toxsci/62.2.236

McIntyre BS, Barlow NJ, Foster PM (2002) Male rats exposed to linuron in utero exhibit permanent changes in anogenital distance, nipple retention, and epididymal malformations that result in subsequent testicular atrophy. Toxicol Sci 65(1):62-70. https:// doi.org/10.1093/toxsci/65.1.62

McKee RH, Pavkov KL, Trimmer GW, Keller LH, Stump DG (2006) An assessment of the potential developmental and reproductive toxicity of di-isoheptyl phthalate in rodents. Reprod Toxicol 21(3):241-252. https://doi.org/10.1016/j.reprotox.2005.09.002

Melching-Kollmuss S, Fussell KC, Schneider S, Buesen R, Groeters S, Strauss V, van Ravenzwaay B (2017) Comparing effect levels of regulatory studies with endpoints derived in targeted anti-androgenic studies: example prochloraz. Arch Toxicol 91(1):143-162. https://doi.org/10.1007/s00204-016-1678-y

Mendiola J, Stahlhut RW, Jorgensen N, Liu F, Swan SH (2011) Shorter anogenital distance predicts poorer semen quality in young men in Rochester, New York. Environ Health Perspect 119(7):958963. https://doi.org/10.1289/ehp.1103421

Miao M, Yuan W, He Y, Zhou Z, Wang J, Gao E, Li G, Li DK (2011) In utero exposure to bisphenol-A and anogenital distance of male offspring. Birth Defects Res A Clin Mol Teratol 91(10):867-872. https://doi.org/10.1002/bdra.22845

Mira-Escolano MP, Mendiola J, Mínguez-Alarcón L, Melgarejo M, Cutillas-Tolín A, Roca M, López-Espín JJ, Noguera-Velasco JA, Torres-Cantero AM (2014) Longer anogenital distance is associated with higher testosterone levels in women: a cross-sectional study. BJOG 121(11):1359-1364. https://doi. org/10.1111/1471-0528.12627

Mitchell RT, Mungall W, McKinnell C, Sharpe RM, Cruickshanks L, Milne L, Smith LB (2015) Anogenital distance plasticity in adulthood: implications for its use as a biomarker of fetal androgen action. Endocrinology 156(1):24-31. https://doi. org/10.1210/en.2014-1534

Money J, Mathews D (1982) Prenatal exposure to virilizing progestins: an adult follow-up study of twelve women. Arch Sex Behav 11(1):73-83. https://doi.org/10.1007/BF01541367

Moore RW, Rudy TA, Lin TM, Ko K, Peterson RE (2001) Abnormalities of sexual development in male rats with in utero and lactational exposure to the antiandrogenic plasticizer di(2-ethylhexyl) phthalate. Environ Health Perspect 109(3):229-237

Mylchreest E, Cattley RC, Foster PM (1998) Male reproductive tract malformations in rats following gestational and lactational exposure to di(n-butyl) phthalate: an antiandrogenic mechanism? Toxicol Sci 43(1):47-60. https://doi.org/10.1006/toxs.1998.2436

Mylchreest E, Sar M, Cattley RC, Foster PM (1999) Disruption of androgen-regulated male reproductive development by di $(n-$ butyl) phthalate during late gestation in rats is different from flutamide. Toxicol Appl Pharmacol 156(2):81-95. https://doi. org/10.1006/taap.1999.8643

Nagao T, Ohta R, Marumo H, Shindo T, Yoshimura S, Ono H (2000) Effect of butyl benzyl phthalate in Sprague-Dawley rats after gavage administration: a two-generation reproductive study. Reprod Toxicol 14(6):513-532. https://doi.org/10.1016/S0890 $-6238(00) 00105-2$

Nakamura N, Inselman AL, White GA, Chang CW, Trbojevich RA, Sephr E, Voris KL, Patton RE, Bryant MS, Harrouk W, McIntyre BS, Foster PM, Hansen DK (2015) Effects of maternal and lactational exposure to 2-hydroxy-4-methoxybenzone on development and reproductive organs in male and female rat offspring. Birth Defects Res B Dev Reprod Toxicol 104(1):35-51. https://doi. org/10.1002/bdrb.21137

Nardelli TC, Albert O, Lalancette C, Culty M, Hales BF, Robaire B (2017) In utero and lactational exposure study in rats to identify replacements for di(2-ethylhexyl) phthalate. Sci Rep 7(1):3862. https://doi.org/10.1038/s41598-017-03979-0

Nef S, Parada LF (1999) Cryptorchidism in mice mutant for Ins13. Nat Genet 22(3):295-299. https://doi.org/10.1038/10364

Noriega NC, Ostby J, Lambright C, Wilson VS, Gray LE Jr (2005) Late gestational exposure to the fungicide prochloraz delays the onset of parturition and causes reproductive malformations in male but not female rat offspring. Biol Reprod 72(6):1324-1335. https:// doi.org/10.1095/biolreprod.104.031385

Notini AJ, Davey RA, McManus JF, Bate KL, Zajac JD (2005) Genomic actions of the androgen receptor are required for normal male sexual differentiation in a mouse model. J Mol Endocrinol 35(3):547-555. https://doi.org/10.1677/jme.1.01884

NTP-National Toxicology Program (2010) Multigenerational reproductive toxicology study of ethinyl estradiol (CAS No. 57-636) in Sprague-Dawley rats. Natl Toxicol Program Tech Rep Ser 547:1-312

OECD (2008) Guidance document on mammalian reproductive toxicity testing and assessment. OECD series on testing and assessment no. 43. http://www.oecd.org/officialdocuments/publicdisplaydo cumentpdf $/$ ?cote $=$ env $/ \mathrm{jm} / \mathrm{mono}(2008) 16 \&$ doclanguage $=e n$. Accessed 1 Jun 2018

OECD (2012) Test no. 443: extended one-generation reproductive toxicity study, OECD guidelines for the testing of chemicals, section 4. OECD Publishing, Paris. https://doi.org/10.1787/97892 64185371-en

OECD (2013) Guidance document in support of the test guideline on the extended one generation reproductive toxicity study no. 151. http://www.oecd.org/officialdocuments/publicdisplaydo cumentpdf/?cote $=\mathrm{ENV} / \mathrm{JM} / \mathrm{MONO}(2013) 10 \&$ doclanguage $=$ en . Accessed 1 Jun 2018

OECD (2015) Feasibility study for minor enhancements of TG 421/422 with ED relevant endpoints. Environment, health and safety publications, series on testing and assessment (no. 217). Paris http://www.oecd.org/officialdocuments/publicdisplaydocumen tpdf $/$ ?cote $=$ env $/ \mathrm{jm} / \mathrm{mono}(2015) 24 \&$ doclanguage $=$ en. Accessed 1 Jun 2018

OECD (2016a) Test no. 421: reproduction/developmental toxicity screening test, OECD guidelines for the testing of chemicals, section 4. OECD Publishing, Paris. https://doi.org/10.1787/97892 64264380-en

OECD (2016b) Test no. 422: combined repeated dose toxicity study with the reproduction/developmental toxicity screening test, OECD guidelines for the testing of chemicals, section 4. OECD Publishing, Paris. https://doi.org/10.1787/9789264264403-en

OECD (2018) Test no. 414: prenatal development toxicity study, OECD guidelines for the testing of chemicals, section 4. OECD Publishing, Paris. https://doi.org/10.1787/9789264070820-en

Ostby JS, Gray LEJ (2004) Transgenerational (in utero/lactational) exposure to investigate the effects of endocrine disrupting compounds (EDCS) in rats. Curr Protoc Toxicol. https://doi. org/10.1002/0471140856.tx1608s19 (Ch 16:unit 16.8)

Ostby J, Kelce WR, Lambright C, Wolf CJ, Mann P, Gray CLJ (1999) The fungicide procymidone alters sexual differentiation in the male rat by acting as an androgen-receptor antagonist in vivo and in vitro. Toxicol Ind Health 15(1-2):80-93. https://doi. org/10.1177/074823379901500108

Parks LG, Ostby JS, Lambright CR, Abbott BD, Klinefelter GR, Barlow NJ, Gray LEJ (2000) The plasticizer diethylhexyl phthalate induces malformations by decreasing fetal testosterone synthesis during sexual differentiation in the male rat. Toxicol Sci 58(2):339-349. https://doi.org/10.1093/toxsci/58.2.339

Ramezani Tehrani F, Noroozzadeh M, Zahediasl S, Piryaei A, Hashemi S, Azizi F (2014) The time of prenatal androgen exposure affects development of polycystic ovary syndrome-like 
phenotype in adulthood in female rats. Int J Endocrinol Metab 12(2):e16502. https://doi.org/10.5812/ijem.16502

Reif DM, Martin MT, Tan SW, Houck KA, Judson RS, Richard AM, Knudsen TB, Dix DJ, Kavlock RJ (2010) Endocrine profiling and prioritization of environmental chemicals using ToxCast data. Environ Health Perspect 118(12):1714-1720. https://doi. org/10.1289/ehp. 1002180

Rosenmai AK, Dybdahl M, Pedersen M, Alice van Vugt-Lussenburg BM, Wedebye EB, Taxvig C, Vinggaard AM (2014) Are structural analogues to bisphenol a safe alternatives? Toxicol Sci 139(1):35-47. https://doi.org/10.1093/toxsci/kfu030

Ryan BC, Hotchkiss AK, Crofton KM, Gray LE Jr (2010) In utero and lactational exposure to bisphenol $\mathrm{A}$, in contrast to ethinyl estradiol, does not alter sexually dimorphic behavior, puberty, fertility, and anatomy of female LE rats. Toxicol Sci 114(1):133-148. https://doi.org/10.1093/toxsci/kfp266

Saillenfait AM, Sabaté JP, Gallissot F (2008) Diisobutyl phthalate impairs the androgen-dependent reproductive development of the male rat. Reprod Toxicol 26(2):107-115. https://doi. org/10.1016/j.reprotox.2008.07.006

Saillenfait AM, Gallissot F, Sabaté JP (2009a) Differential developmental toxicities of di- $n$-hexyl phthalate and dicyclohexyl phthalate administered orally to rats. J Appl Toxicol 29(6):510-521. https://doi.org/10.1002/jat.1436

Saillenfait AM, Sabaté JP, Gallissot F (2009b) Effects of in utero exposure to di- $n$-hexyl phthalate on the reproductive development of the male rat. Reprod Toxicol 28(4):468-476. https:// doi.org/10.1016/j.reprotox.2009.06.013

Saillenfait AM, Roudot AC, Gallissot F, Sabaté JP (2011) Prenatal developmental toxicity studies on di- $n$-heptyl and di- $n$-octyl phthalates in Sprague-Dawley rats. Reprod Toxicol 32(3):268276. https://doi.org/10.1016/j.reprotox.2011.08.001

Saillenfait AM, Gallissot F, Sabaté JP, Remy A (2013) Prenatal developmental toxicity studies on diundecyl and ditridecyl phthalates in Sprague-Dawley rats. Reprod Toxicol 37:49-55. https://doi.org/10.1016/j.reprotox.2013.01.004

Saillenfait AM, Sabaté JP, Denis F, Antoine G, Robert A, Roudot AC, Ndiaye D, Eljarrat E (2017) Evaluation of the effects of $\alpha$-cypermethrin on fetal rat testicular steroidogenesis. Reprod Toxicol 72:106-114. https://doi.org/10.1016/j.repro tox.2017.06.133

Salazar-Martinez E, Romano-Riquer P, Yanez-Marquez E, Longnecker MP, Hernandez-Avila M (2004) Anogenital distance in human male and female newborns: a descriptive, cross-sectional study. Environ Health 3(1):8. https://doi. org/10.1186/1476-069X-3-8

Satoh K, Nonaka R, Ohyama K, Nagai F (2005) Androgenic and antiandrogenic effects of alkylphenols and parabens assessed using the reporter gene assay with stably transfected CHOK1cells (AR-EcoScreen System). J Health Sci 51:557-568. https ://doi.org/10.1248/jhs.51.557

Sawaki M, Noda S, Muroi T, Mitoma H, Takakura S, Sakamoto S, Yamasaki K (2003) In utero through lactational exposure to ethinyl estradiol induces cleft phallus and delayed ovarian dysfunction in the offspring. Toxicol Sci 75(2):402-411. https://doi. org/10.1093/toxsci/kfg180

Schneider S, Kaufmann W, Strauss V, van Ravenzwaay B (2011) Vinclozolin: a feasibility and sensitivity study of the ILSI-HESI F1-extended one-generation rat reproduction protocol. Regul Toxicol Pharmacol 59(1):91-100. https://doi.org/10.1016/j.yrtph .2010.09.010

Scott HM, Hutchison GR, Mahood IK, Hallmark N, Welsh M, De Gendt K, Verhoeven H, O'Shaughnessy P, Sharpe RM (2007) Role of androgens in fetal testis development and dysgenesis. Endocrinology 148(5):2027-2036. https://doi.org/10.1210/ en.2006-1622
Scott HM, Hutchison GR, Jobling MS, McKinnell C, drake Sharpe AJ RM (2008) Relationship between androgen action in the "male programming window," fetal sertoli cell number, and adult testis size in the rat. Endocrinology 149(10):5280-5287. https://doi. org/10.1210/en.2008-0413

Singal AK, Jain VG, Gazali Z, Shekhawat P (2016) Shorter anogenital distance correlates with the severity of hypospadias in pre-pubertal boys. Hum Reprod 31(7):1406-1410. https://doi.org/10.1093/ humrep/dew115

Skakkebaek NE, Rajpert-De Meyts E, Buck Louis GM, Toppari J, Andersson AM, Eisenberg ML, Jensen TK, Jørgensen N, Swan SH, Sapra KJ, Ziebe S, Priskorn L, Juul A (2016) Male reproductive disorders and fertility trends: influences of environment and genetic susceptibility. Physiol Rev 96(1):55-97. https://doi. org/10.1152/physrev.00017.2015

Stewart MK, Mattiske DM, Pask AJ (2018) In utero exposure to both high and low dose diethylstilbestrol disrupts mouse genital tubercle development. Biol Reprod. https://doi.org/10.1093/biolre/ ioy 142 (in press)

Suzuki Y, Yoshinaga J, Mizumoto Y, Serizawa S, Shiraishi H (2012) Foetal exposure to phthalate esters and anogenital distance in male newborns. Int J Androl 35(3):236-244. https://doi.org/10. 1111/j.1365-2605.2011.01190.x

Svechnikov K, Izzo G, Landreh L, Weisser J, Söder O (2010) Endocrine disruptors and Leydig cell function. J Biomed Biotechnol 2010:684504. https://doi.org/10.1155/2010/684504

Svechnikov K, Savchuk I, Morvan ML, Antignac JP, Le Bizec B, Söder O (2016) Phthalates exert multiple effects on Leydig cell steroidogenesis. Horm Res Paediatr 86(4):253-263. https://doi. org/10.1159/000440619

Svingen T, Koopman P (2013) Building the mammalian testis: origins, differentiation, and assembly of the component cell populations. Genes Dev 27(22):2409-2426. https://doi.org/10.1101/ $\operatorname{gad} .228080 .113$

Swan SH, Main KM, Liu F, Stewart SL, Kruse RL, Calafat AM, Mao CS, Redmon JB, Ternand CL, Sullivan S, Teague JL, Team SfFFR (2005) Decrease in anogenital distance among male infants with prenatal phthalate exposure. Environ Health Perspect 113(8):1056-1061. https://doi.org/10.1289/ehp.8100

Takagi H, Shibutani M, Masutomi N, Uneyama C, Takahashi N, Mitsumori K, Hirose M (2004) Lack of maternal dietary exposure effects of bisphenol A and nonylphenol during the critical period for brain sexual differentiation on the reproductive/endocrine systems in later life. Arch Toxicol 78(2):97-105. https://doi. org/10.1007/s00204-003-0517-0

Taxvig C, Hass U, Axelstad M, Dalgaard M, Boberg J, Andreasen HR, Vinggaard AM (2007) Endocrine-disrupting activities in vivo of the fungicides tebuconazole and epoxiconazole. Toxicol Sci 100(2):464-473. https://doi.org/10.1093/toxsci/kfm227

Taxvig C, Vinggaard AM, Hass U, Axelstad M, Metzdorff S, Nellemann C (2008) Endocrine-disrupting properties in vivo of widely used azole fungicides. Int J Androl 31(2):170-177. https://doi. org/10.1111/j.1365-2605.2007.00838.x

Thankamony A, Ong KK, Dunger DB, Acerini CL, Hughes IA (2009) Anogenital distance from birth to 2 years: a population study. Environ Health Perspect 117(11):1786-1790. https://doi. org/10.1289/ehp.0900881

Thankamony A, Lek N, Carroll D, Williams M, Dunger DB, Acerini CL, Ong KK, Hughes IA (2014) Anogenital distance and penile length in infants with hypospadias or cryptorchidism: comparison with normative data. Environ Health Perspect 122(2):207211. https://doi.org/10.1289/ehp.1307178

Thankamony A, Pasterski V, Ong KK, Acerini CL, Hughes IA (2016) Anogenital distance as a marker of androgen exposure in humans. Andrology 4(4):616-625. https://doi.org/10.1111/andr.12156 
Tinwell H, Haseman J, Lefevre PA, Wallis N, Ashby J (2002) Normal sexual development of two strains of rat exposed in utero to low doses of bisphenol A. Toxicol Sci 68:339-348. https://doi. org/10.1093/toxsci/68.2.339

Turner KJ, Barlow NJ, Struve MF, Wallace DG, Gaido KW, Dorman DC, Foster PM (2002) Effects of in utero exposure to the organophosphate insecticide fenitrothion on androgen-dependent reproductive development in the $\mathrm{Crl}: \mathrm{CD}(\mathrm{SD}) \mathrm{BR}$ rat. Toxicol Sci 68(1):174-183. https://doi.org/10.1093/toxsci/68.1.174

Tyl RW, Myers CB, Marr MC, Fail PA, Seely JC, Brine DR, Barter RA, Butala JH (2004) Reproductive toxicity evaluation of dietary butyl benzyl phthalate (BBP) in rats. Reprod Toxicol 18(2):241264. https://doi.org/10.1016/j.reprotox.2003.10.006

Vafeiadi M, Agramunt S, Papadopoulou E, Besselink H, Mathianaki K, Karakosta P, Spanaki A, Koutis A, Chatzi L, Vrijheid M, Kogevinas M (2013) In utero exposure to dioxins and dioxin-like compounds and anogenital distance in newborns and infants. Environ Health Perspect 121(1):125-130. https://doi.org/10.1289/ ehp. 1205221

van den Driesche S, Kolovos P, Platts S, Drake AJ, Sharpe RM (2012) Inter-relationship between testicular dysgenesis and Leydig cell function in the masculinization programming window in the rat. PloS One 7(1):e30111. https://doi.org/10.1371/journ al.pone. 0030111

van den Driesche S, Macdonald J, Anderson RA, Johnston ZC, Chetty T, Smith LB, Mckinnell C, Dean A, Homer NZ, Jorgensen A, Camacho-Moll ME, Sharpe RM, Mitchell RT (2015) Prolonged exposure to acetaminophen reduces testosterone production by the human fetal testis in a xenograft model. Sci Transl Med 7(288):288ra80. https://doi.org/10.1126/scitranslmed.aaa4097

van den Driesche S, Kilcoyne KR, Wagner I, Rebourcet D, Boyle A, Mitchell RT, McKinnell C, Macpherson S, Donat R, Shukla CJ, Jorgensen A, Meyts ER, Skakkebaek NE, Sharpe RM (2017) Experimentally induced testicular dysgenesis syndrome originates in the masculinization programming window. JCI Insight 2(6):e91204. https://doi.org/10.1172/jci.insight.91204

Vinggaard AM, Joergensen EC, Larsen JC (1999) Rapid and sensitive reporter gene assays for detection of antiandrogenic and estrogenic effects of environmental chemicals. Toxicol Appl Pharmacol 155(2):150-160. https://doi.org/10.1006/taap.1998.8598

Vinggaard AM, Christiansen S, Laier P, Poulsen ME, Breinholt V, Jarfelt K, Jacobsen H, Dalgaard M, Nellemann C, Hass U (2005) Perinatal exposure to the fungicide prochloraz feminizes the male rat offspring. Toxicol Sci 85(2):886-897. https://doi.org/10.1093/ toxsci/kfi150

Vinggaard AM, Hass U, dalgaard M, Andersen HR, BonefeldtJørgensen E, Christiansen S, Laier P, Poulsen ME (2006) Prochloraz: an imidazole fungicide with multiple mechanisms of action. Int J Androl 29(1):186-192. https://doi.org/10.111 $1 /$ j.1365-2605.2005.00604.x
Welsh M, Saunders PT, Sharpe RM (2007) The critical time window for androgen-dependent development of the Wolffian duct in the rat. Endocrinology 148(7):3185-3195. https://doi.org/10.1210/ en.2007-0028

Welsh M, Saunders PT, Fisken M, Scott HM, Hutchison GR, Smith LB, Sharpe RM (2008) Identification in rats of a programming window for reproductive tract masculinization, disruption of which leads to hypospadias and cryptorchidism. J Clin Investig 118(4):1479-1490. https://doi.org/10.1172/JCI34241

Welsh M, MacLeod DJ, Walker M, Smith LB, Sharpe RM (2010) Critical androgen-sensitive periods of rat penis and clitoris development. Int J Androl 33(1):e144-e152. https://doi.org/10.111 1/j.1365-2605.2009.00978.x

Wilkins L, Jones HWJ, Holman GH, Stempfel RSJ (1958) Masculinization of the female fetus associated with administration of oral and intramuscular progestins during gestation: non-adrenal female pseudohermaphrodism. J Clin Endocrinol Metab 18(6):559-585. https://doi.org/10.1210/jcem-18-6-559

Williams K, McKinnell C, Saunders PT, Walker M, Fisher JS, Turner KJ, Atanassova N, Sharpe M (2001) Neonatal exposure to potent and environmental oestrogens and abnormalities of the male reproductive system in the rat: evidence for importance of the androgen-oestrogen balance and assessment of the relevance to man. Hum Reprod Update 7(3):236-247. https://doi.org/10.1093/ humupd/7.3.236

Wolf CJJ, Lambright C, Mann P, Price M, Cooper RL, Ostby J, Gray CLJ (1999) Administration of potentially antiandrogenic pesticides (procymidone, linuron, iprodione, chlozolinate, $p, p^{\prime}$ DDE, and ketoconazole) and toxic substances (dibutyl- and diethylhexyl phthalate, PCB 169, and ethane dimethane sulphonate) during sexual differentiation produces diverse profiles of reproductive malformations in the male rat. Toxicol Ind Health 15(1-2):94-118. https://doi.org/10.1177/074823379901500109

Wolf CJ, Hotchkiss A, Ostby JS, LeBlanc GA, Gray LE Jr (2002) Effects of prenatal testosterone propionate on the sexual development of male and female rats: a dose-response study. Toxicol Sci 65(1):71-86. https://doi.org/10.1093/toxsci/65.1.71

Wolf CJ, LeBlanc GA, Gray LE Jr (2004) Interactive effects of vinclozolin and testosterone propionate on pregnancy and sexual differentiation of the male and female SD rat. Toxicol Sci 78(1):135143. https://doi.org/10.1093/toxsci/kfh018

Wu Y, Zhong G, Chen S, Zheng C, Liao D, Xie M (2017) Polycystic ovary syndrome is associated with anogenital distance, a marker of prenatal androgen exposure. Hum Reprod 32(4):937-943. https://doi.org/10.1093/humrep/dex042

Zhang L, Dong L, Ding S, Qiao P, Wang C, Zhang M, Zhang L, Du Q, Li Y, Tang N, Chang B (2014) Effects of $n$-butylparaben on steroidogenesis and spermatogenesis through changed E2 levels in male rat offspring. Environ Toxicol Pharmacol 37(2):705-717. https://doi.org/10.1016/j.etap.2014.01.016 